\title{
Recent Advances in Structured Catalysts Preparation and Use in Water-Gas Shift Reaction
}

\author{
Vincenzo Palma, Concetta Ruocco $\mathbb{D}^{D}$, Marta Cortese and Marco Martino * \\ Department of Industrial Engineering, University of Salerno, Via Giovanni Paolo II 132, 84084 Fisciano (SA), \\ Italy; vpalma@unisa.it (V.P.); cruocco@unisa.it (C.R.); marta.cortese90@gmail.com (M.C.) \\ * Correspondence: mamartino@unisa.it; Tel.: +39-089-964027
}

Received: 31 October 2019; Accepted: 20 November 2019; Published: 26 November 2019

\begin{abstract}
The water-gas shift reaction plays a key role in hydrogen production processes from fossil sources and renewable biomass feedstock and can be considered as the first purification process of syngas. The water gas shift process is normally carried out in two adiabatic stages, of high and low temperature with an intersystem cooling. The two stages use two different catalytic systems, which present some critical issues, thus making extremely attractive the designing and implementing of new configurations. Innovative and highly active catalytic formulations along with more efficient reactor systems could provide the basis for the design of a single-stage process, resulting in a noticeable process intensification. In the last decades, much attention has been paid to the use of structured catalysts, which have numerous advantages, related to both fluid dynamics and heat transfer phenomena. Numerous papers have been published in which the competitive performances of structured catalysts have been shown with respect to conventional catalytic systems. In this brief review, we provide an overview of the most recent developments in the preparation of structured catalysts and use in the water gas shift reaction.
\end{abstract}

Keywords: water gas shift; structured catalysts preparation; thermal conductivity; kinetics

\section{Introduction}

The water gas shift (WGS) is one of the most studied reaction involved in the production process of hydrogen, hydrocarbons and several industrial feedstocks. Operating downstream the reforming processes, reduces the carbon monoxide percentage, in syngas stream to less than $0.3 \mathrm{vol} \%$, producing, at the same time, hydrogen [1].

WGS is a reversible exothermic reaction (1), and like all this type of reactions, it suffers from limitations of kinetic and thermodynamic type. At low temperatures, where it is favoured thermodynamically, the reaction rate is low, vice versa at high temperatures the opposite occurs.

$$
\mathrm{CO}+\mathrm{H}_{2} \mathrm{O} \rightleftarrows \mathrm{H}_{2}+\mathrm{CO}_{2} \Delta \mathrm{H}_{298 \mathrm{~K}}^{0}=41.17 \mathrm{~kJ} / \mathrm{mol}
$$

Under adiabatic conditions, the thermal profile on the catalytic bed is kinetically disadvantageous at the inlet of the bed, and thermodynamically disadvantageous at the outlet of the bed. The strategy to overcome these limitations is the multi-stage configuration, which consists in sectioning the process in several stages at different temperatures, followed by heat dissipating stages realized by intermediate cooling. The used WGS process configuration, provides two steps (Figure 1), and an intermediate cooling, the high temperature shift (HTS) [2] and the low temperature shift (LTS). 


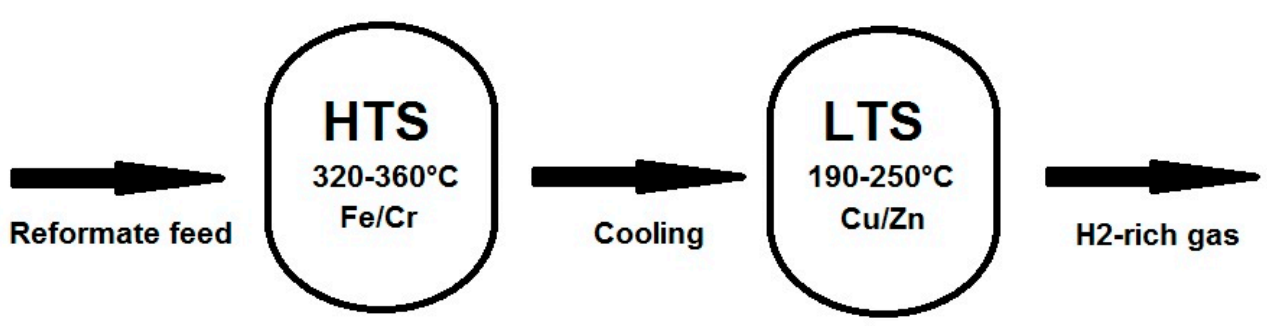

Figure 1. Schematic representation of the two-stage WGS process configuration.

The disadvantages of this approach are known, both in terms of energy consumption and fixed costs. In the last decade, many works were published focusing on the intensification of WGS process using structured catalysts. Structured catalysts present several advantages, low pressure drops [3], efficient heat and mass transfer [4,5] and good mechanical stability [6]. Highly thermal conductive structures allow to manage the heat of the reaction in a completely different way, compared to the traditional packed bed reactors, providing beneficial effects on both kinetic and thermodynamic [7]. The objective of this short review is to report the recent advances in the preparation techniques of structured catalysts and to show the most recent developments in the use of structured catalysts for water gas shift applications. The review article is organized in three main sections, the first one gives an overview on the most diffused preparation methods for the structured supports, moreover the most used coating techniques are illustrated. Furthermore, a series of works about the catalytic activity and kinetics is reported, finally an overview of the theoretical and modelling studies concerning the transport phenomena in structured catalysts is provided.

\section{Structured Catalysts Preparation}

Structured catalysts are characterized by a fixed geometry and prepared by coupling a catalytically inert structure, which provides the geometry and a catalytic formulation, which is usually supported on the structure. The structure can be ceramic or metal in nature [8]; and sometimes it is necessary to use a compatibilizer, to realize a strong adhesion between the surface of the structure and the catalytic formulation. The geometry of the structure plays a leading role in the design of these catalysts, as it is directly involved in mass and heat transfer phenomena. Many geometries are available, however the most used are monoliths and foams.

\subsection{The Structures}

Monoliths are blocks consisting of parallel channels characterized by different shapes and sizes; ceramic monoliths, mostly made by cordierite and silicon carbide, are usually obtained by extrusion [9], two main designs are available, the flow-through configuration in which every channel is open on both side, and the wall-flow configuration in which the channels are alternatively closed, and the stream is forced to flow through the porous walls [10]. In the case of metal monoliths, the preparation techniques depend from the used alloy; in addition to extrusion, the rolling and the piling of crimped foils [5,11-13] (Figure 2) and the perforated Lessing rings [14] allow to realize a wide variety of shapes and sizes of the channels. Metal monoliths exhibit higher mechanical strength and thermal conductivity, furthermore the possibility of creating thinner walls allows a higher cell density and lower pressure drops, with respect to the ceramic monoliths.

Foams are characterized by a three-dimensional array of empty polygons; the most attractive type for catalysis applications are the open-cell foams, in which the cells are communicating. Among the preparation methods for ceramic foams [15], the "polymeric sponge method" [16,17] and the "bubble generation method" [18,19] are the most used, however the latter is suitable to prepare only small closed-cell foams. The preparation methods of metallic foams can be classified depending on the state of the metal to be used, liquid or solid. Molten metals can be used in direct foaming by gasses or casting the liquid in a discontinuous solid filling material, such as granules or spheres [20]. The metal 
powders can be used to fill a mould and then sintered, or mixed with a fluid carrier, a solvent or a polymeric binder; thereafter, the foaming agent is removed and the metal structure is obtained by sintering in an inert or reducing atmosphere [21].

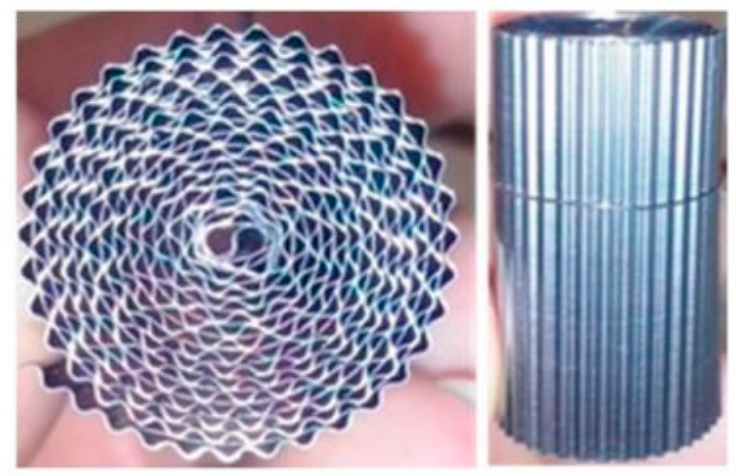

Figure 2. Cylindrical monolith obtained by rolling FeCrAlloy foil [13].

The need for complex shapes has favoured, in recent years, the development of the so-called "additive manufacturing approach", which overturn the subtractive approach. The production of three-dimensional objects is achieved by depositing or sintering the build materials, based on coordinates derived from a digital model, through a computer-controlled positioning system [22], also referred as 3D printing. With these techniques, traditional geometric shapes, such as monoliths, hybrid forms or complex shapes tailored to a specific process, can be obtained.

\subsection{Coating Techniques}

In this section, an overview of the main coating techniques used to load the active formulations on the structured support, is provided (Table 1). The choice of the coating technique depends on numerous factors: the type of structure (metallic or ceramic), the textural properties of the structure (porosity, channel size, relative density etc.), reactivity of the coating compound, type of process in which the catalyst should be used.

Impregnation can be used on ceramic structures such as silicon carbide [23] and cordierite [24], characterized by porous and roughness surfaces. Ahn and Lee reported the preparation of monolith catalysts obtained by impregnation in aluminum or cobalt nitrate solution, drying and calcination at $600{ }^{\circ} \mathrm{C}$, followed by impregnation of gold and platinum, using $\mathrm{NH}_{4} \mathrm{HCO}_{3}$ [25]. The TEM images showed that the gold particles were uniformly dispersed, and the average size was about $5 \mathrm{~nm}$. Even if impregnation is a simple and fast method, it is suitable in the cases in which there is no need of high surface areas, but it is not suitable for metal structures. The sol-gel preparations are based on the formation of a colloidal solution (sol), obtained by hydrolysis and condensation of the soluble precursors, such as metallic, organometallic or alkoxides precursors [26]. Upon further condensation, the sol gives rise to an integrated network (gel), containing solvent molecules trapped, finally the gel can be converted to solid material by removing the solvent through drying and/or thermal treatments $[27,28]$. Films of variable thicknesses can be realized by dip-coating or spin-coating of the structures, making this technique effective and not expensive. Solution combustion synthesis can be considered a variant of the sol-gel method; it is based on a self-sustained redox reaction, in which an organic material acts as fuel, for example urea or glycine, while the oxidant is a metal precursor, such as a metal nitrate [29]. Recently, Ercolino et al. reported the coating of alumina monolith and open cell foams by solution combustion synthesis [30]. The structures were previously cleaned in an ultrasonic bath with an aqueous solution of acetone $(50 \mathrm{wt} \%)$, then dried for $1 \mathrm{~h}$ at $250{ }^{\circ} \mathrm{C}$. The as obtained structures were dipped in a $3 \mathrm{M}$ solution of cobalt nitrate and glycine for $3 \mathrm{~min}$ and calcined at $600{ }^{\circ} \mathrm{C}$ for $4 \mathrm{~h}$ in calm air. The coated structures were subsequently impregnated with palladium precursor solution. The average thickness of the catalytic layer determined from FESEM images was 
around $30-50 \mathrm{~mm}$, the images at high magnification on both the monolith and foams confirmed the typical truncated octahedron crystals structure of the coated spinel, the images at medium and low magnification showed that the deposited catalytic layer was homogeneously distributed and well anchored on both the structures, without superficial debris. The ultrasound adhesion tests showed an average weight loss less than $1.5 \%$, highlighting the high mechanical resistance of the coating obtained by solution combustion synthesis.

Several deposition techniques are available for both ceramic and metal structures. The electrodeposition employs electricity and can be applied onto a conductive substrate surface. Basile et al. reported the deposition of a Ni/Al- $\mathrm{NO}_{3} \mathrm{HT}$ film on metallic FeCrAlloy foams, by cathodic reduction of a $0.03 \mathrm{M}$ solution containing $\mathrm{Ni}\left(\mathrm{NO}_{3}\right)_{2} \cdot 6 \mathrm{H}_{2} \mathrm{O}, \mathrm{Al}\left(\mathrm{NO}_{3}\right)_{3} \cdot 9 \mathrm{H}_{2} \mathrm{O}$ (molar ratio 3/1) and $0.3 \mathrm{M} \mathrm{KNO}_{3}$ [31]. Electrochemical synthesis was carried out at room temperature by using a single-compartment, three electrode cells, at three different depositions times $(600,1000$ and $1800 \mathrm{~s})$ and two different potentials $(-0.9$ and $-1.2 \mathrm{~V})$. The deposition time affected the film thickness and the $\mathrm{Ni}$ incorporation, while the applied potential affected the $\mathrm{pH}$ in proximity of the foam. SEM was used to assess film stability after $40 \mathrm{~min}$ of ultrasonication. The images showed that a partially detachment of the film occurred for the catalysts obtained in a shorter time regardless of the potential used. On the contrary, the morphology of the catalyst layer remained almost unmodified for the catalysts obtained in longer times. More recently, Ho et al. tested the use of electrodeposition for the in-situ synthesis of cerium-based coatings, $\mathrm{CeO}_{2}$ and $\mathrm{Pd}-\mathrm{CeO}_{2}$, on 100 pores per inch (ppi) FeCrAl foams [32]. Of particular interest is the most challenging one-step $\mathrm{Pd}-\mathrm{CeO}_{2}$ electrodeposition, that was realized by using $\mathrm{Pd}\left(\mathrm{NH}_{3}\right)_{4}\left(\mathrm{NO}_{3}\right)_{2}$ or $\mathrm{PdCl}_{2}$ in $\mathrm{HCl}$ precursors. The electrochemistry and chemistry of palladium (II) ions played a crucial role in the one-step preparation of the $\mathrm{Pd}-\mathrm{CeO}_{2}$ coating. The palladium precursor determined the metal content and distribution as well as the morphology of the ceria particles; the $\left[\mathrm{Pd}\left(\mathrm{NH}_{3}\right)_{4}\right]^{2+}$ complex, due to its intermediate degree of stability in basic media, increased the reduction potential, delaying the formation of $\mathrm{Pd}^{\circ}$ but also the palladium incorporation in ceria. The best conditions to increase the palladium loading, limiting the $\mathrm{Pd}^{\circ}$ deposition, were found in a $-1.3 \mathrm{~V}$ vs. SCE potential combined with a $0.135 \mathrm{M}$ electrolyte concentration and $1000 \mathrm{~s}$ deposition time.

Electrophoretic deposition is a process in which a direct current electric field is applied to a stable suspension of charged particles attracting them to an oppositely charged electrode [33,34]. Moritz et al. reported the coating of carbon-bounded foam filters with aluminum powder by using electrophoretic deposition [35]. The $\mathrm{Al}_{2} \mathrm{O}_{3}$-C filters were prepared via the Schwartzwalder-Somers method, i.e., by the replication of polyurethane foam. The coating was realized by using a $10 \mathrm{vol} \%$ suspension of $\alpha$-alumina and $2.0 \mathrm{~g}$ of Dolapix CA per $100 \mathrm{~g}$ of $\mathrm{Al}_{2} \mathrm{O}_{3}$; two platinum sheets acted as counter electrodes at a distance of $40 \mathrm{~mm}$, the $\mathrm{Al}_{2} \mathrm{O}_{3}-\mathrm{C}$ served as deposition electrode (anode) at a distance of $12.5 \mathrm{~mm}$ from each platinum electrode. The applied voltage was $5-15 \mathrm{~V}$, while the time 1-2 min. The electroless deposition [36] is realized by deposition and reduction of metallic ions at the surface of the support, from a solution without electricity. Fukuhara et al. prepared plate-type catalysts for the wall-type $\mathrm{CO}$ shift converter by electroless plating of zinc and copper on aluminum plate [37]. The plates were dipped in a zinc oxide plating bath $\left(\mathrm{ZnO} 50 \mathrm{~g} / \mathrm{L}, \mathrm{NaOH} 60 \mathrm{~g} / \mathrm{L}, 20^{\circ} \mathrm{C}, 3 \mathrm{~min}\right)$ to displace surface aluminum with zinc, then the plates were washed in a water bath two times. Subsequently, the plates were immersed in plating baths of various metals. Four kinds of metal plating baths were used: (a) An iron bath, (b) a nickel bath, (c) a cobalt bath, and (d) a tin bath.

An interesting alternative is represented by the coating techniques used in surface protection, such as gas-phase based deposition techniques, physical vapour deposition (PVD) and chemical vapour deposition (CVD), or liquid-based chemical conversion coating (CCC). In PVD the material is vaporized from a solid or liquid source, through vacuum or low-pressure gases and condensed onto the support [38]. In CVD [39] the deposition involves chemical reaction of gaseous reactants on the heated substrate surface, while the activation of the substrate is usually performed by heating, radiation or plasma [40]. Minett et al. reported the one-step production of monolith-supported long carbon nanotube arrays by catalytic chemical vapour deposition on the walls of bare cordierite [41]. 
The monolith was heated under argon atmosphere until reaching the temperature of $790{ }^{\circ} \mathrm{C}$. Then, a solution of toluene and ferrocene $(0.1 \mathrm{M})$ was injected into the first zone of the furnace at $300{ }^{\circ} \mathrm{C}$, ensuring that the concentration of both ferrocene and toluene was not limiting growth. The atomic layer deposition (ALD) process provides a series of sequential alternating pulses in which the precursor, in a chamber vacuum, react with the surface through a self-limiting process [42]. Lee et al. reported the deposition of $\mathrm{ZnO}$ on porous alumina monoliths by atomic layer deposition from diethylzinc and water [43]; the study showed that the ALD process in the nanoporous monolith, in which the aspect ratio was higher than $10^{5}$, was limited by the Knudsen diffusion of diethylzinc within the pores. The main advantage in using ALD, with respect CVD, is the powerful of the pulse method in realizing a uniform growth of the layer, moreover layers of two or more different precursors can be easily realized.

The chemical coating is mainly used in the corrosion field [44,45]; the main advantage in using this technique is that the metal surface to be coated does not need to be electrochemically conductive [46]. Palma et al. reported the preparation of structured catalysts obtained by cerium conversion coating of aluminum foams [47].

The ceria coating was realized by reacting the structures in a chemical bath, obtained by dissolving $\mathrm{CeCl}_{3} \times 7 \mathrm{H}_{2} \mathrm{O}, \mathrm{H}_{2} \mathrm{O}_{2} 35 \mathrm{wt} \%$ in water, in a weight ratio $1 / 3 / 75$, acidified with $\mathrm{HCl}(\mathrm{pH}=1-3)$. The results showed that the loading of ceria depend on the temperature, $\mathrm{pH}$ of the bath and the reaction time; specifically, an increase in temperature and times and a reduction in the reaction $\mathrm{pH}$ favours the coating (Figure 3). The SEM images reported in Figure 4 show the morphology of a ceria coated aluminum foam at different magnification. The coating was realized by means of chemical conversion coating.
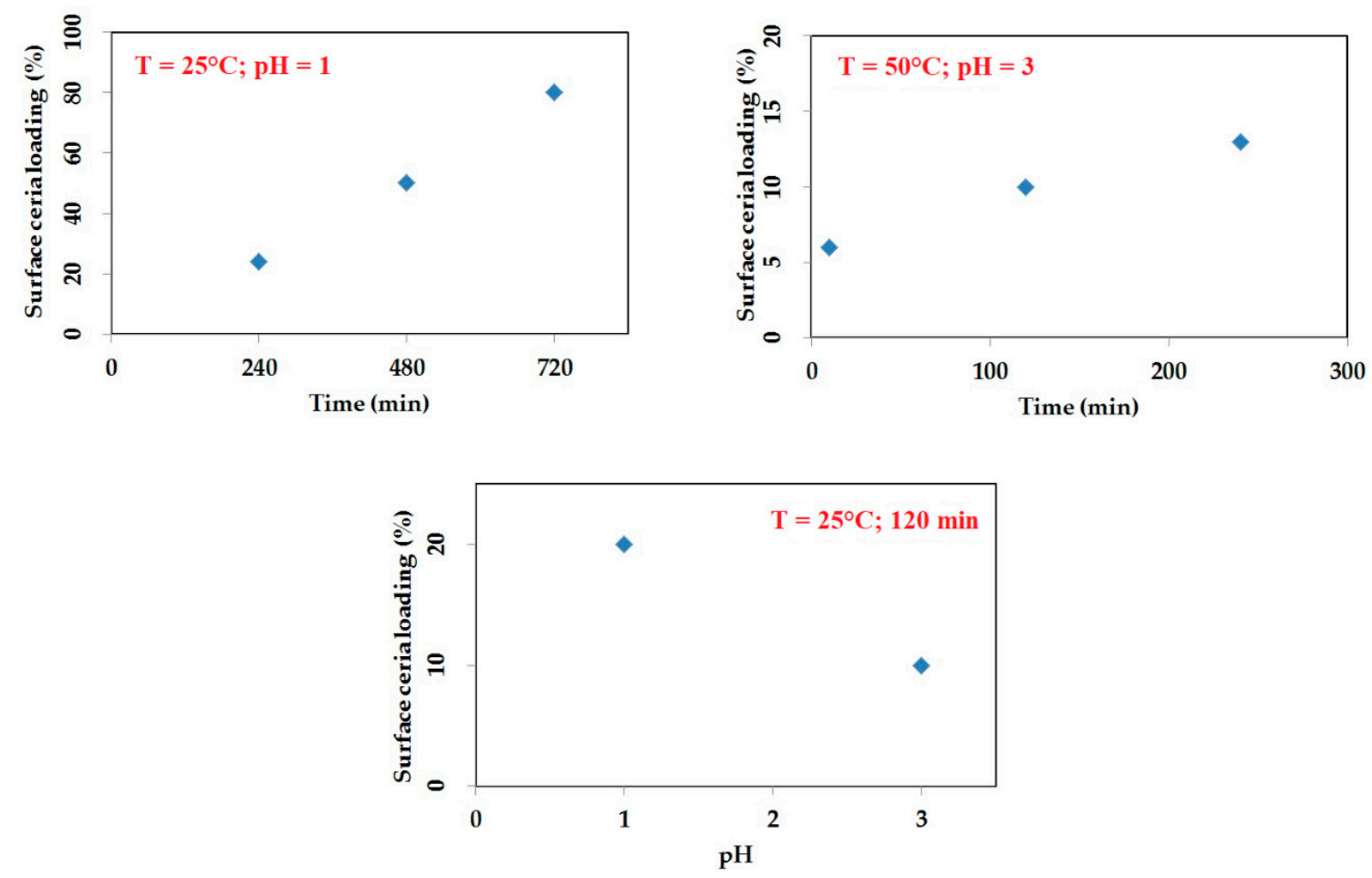

Figure 3. Correlation between surface ceria loading and reaction parameters in chemical conversion coating technique [47].

Washcoating is a widely used techniques to realize structured catalysts [49-51]. It consists in dipping the structure in a colloidal suspension, to realize a coating of an oxide that can be a support for active species, or simply a primer, to make compatible the surface support with the active components [52]. The most used material to realize the colloid is high specific surface area alumina [53], while the procedures to dip the structure are dip-coating or dip-blowing; the excess of the slurry is removed by vacuum suction, centrifuge or with a flow of compressed air or nitrogen [54]. 


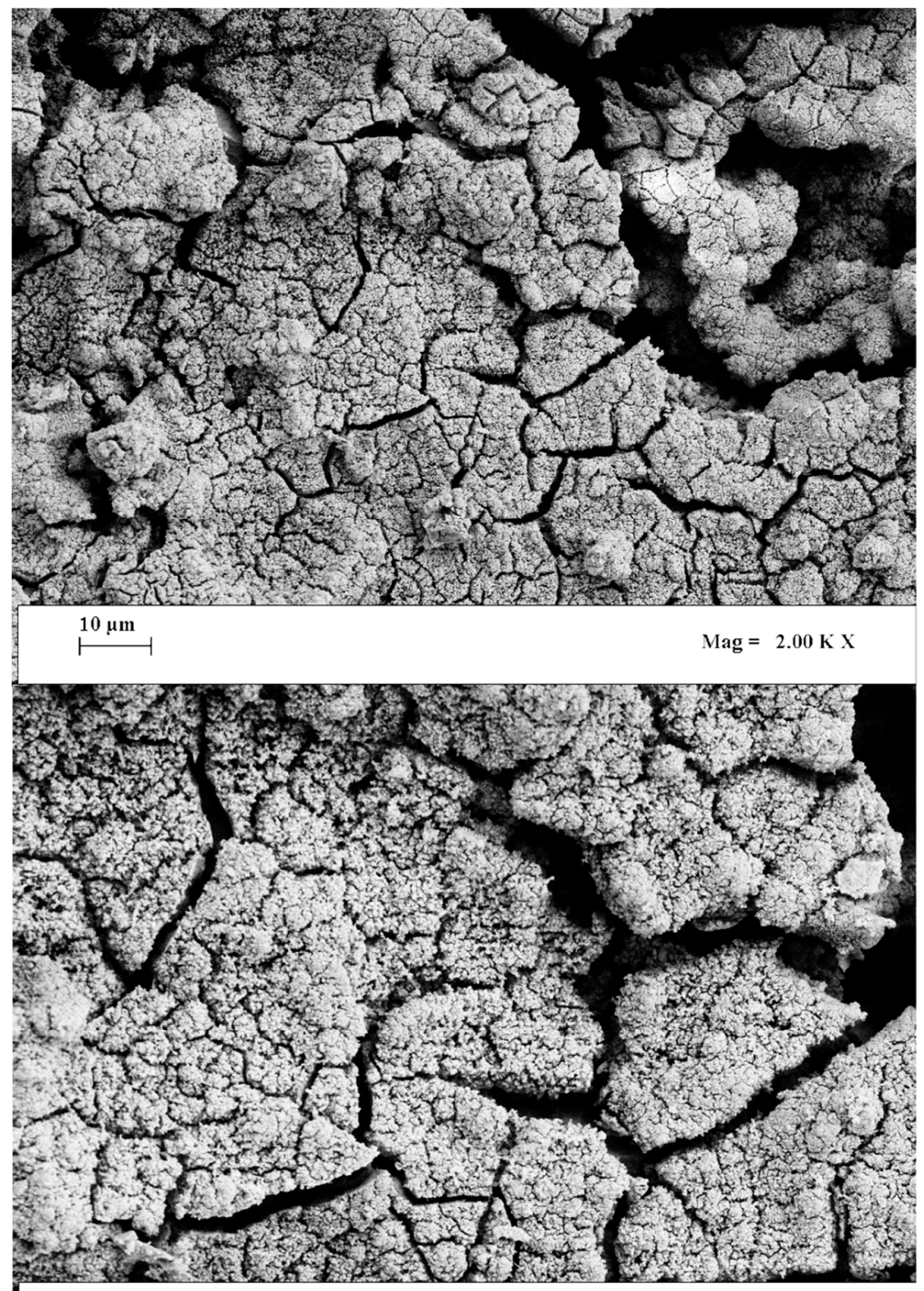

$\operatorname{Mag}=5.00 \mathrm{~K} \mathrm{X}$

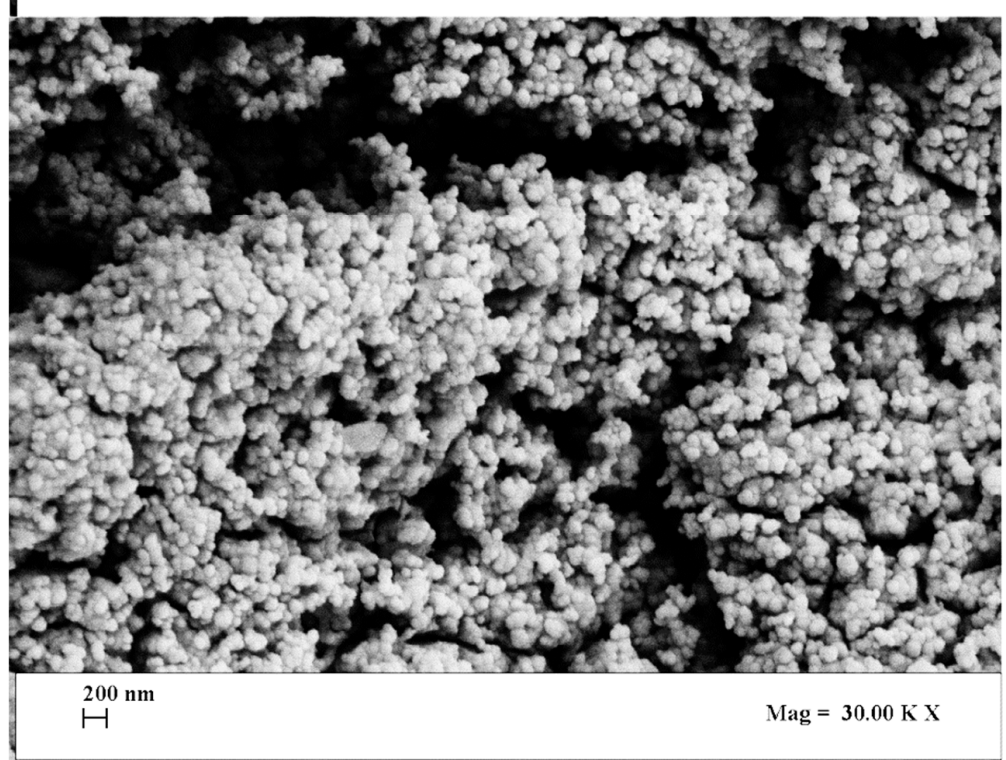

Figure 4. SEM images of ceria coated aluminum foam (5PPI, relative density 10\%) [48]. 
Rao Peela et al. studied the washcoating of r-alumina on stainless steel microchannels [55], focusing on the effect of primer and slurry composition. The washcoating procedure consisted of two steps, primer coating followed by slurry coating. The optimum primer composition was found to be $2 \%$ of Disperal and $4 \%$ PVA. To determine the best slurry composition, several parameters were studied, such as $\mathrm{pH}$, viscosity and solid loading. PVA was found to increase the binding and enhance the viscosity, resulting in better adherence; however, it caused a reduction of the surface area. Uniform well-adhered washcoats were obtained with particle size of $x$-alumina less than $3 \mathrm{~mm}$, and slurry composition: $14 \mathrm{wt} . \%$ r-alumina, $2 \mathrm{wt} . \%$ PVA, $6 \mathrm{wt} . \%$ colloidal alumina in water. Cristiani et al. studied the effects of the chemical composition of suspensions on the slurry rheology [56]. The results of the study showed that the viscosity of the suspensions can be easily predicted and controlled by knowing the pore volume and the nature of the surface of the dispersed powders. Moreover, the maximum surface charging, determined according to surface titration with a strong acid such as $\mathrm{HNO}_{3}$, has been found to be a good parameter to be used for the definition of the amount of dispersant to be added in the slurry. Katheria et al. studied the effect of some process parameters on the washcoating of $\mathrm{Ni} / \mathrm{MgAl}_{2} \mathrm{O}_{4}$ on FeCralloy foils and monoliths [57]. Washcoating parameters, such as calcination temperature, type of binders, particle size and rheological properties of the slurry after ball milling. Slurry milling for $48 \mathrm{~h}$ (average particle size $\approx 2 \mu \mathrm{m}$ ) at $\mathrm{pH} 2-4$ was found to be most stable and resulted in homogeneous washcoating. Increasing the calcination temperature after washcoating from 600 to $800{ }^{\circ} \mathrm{C}$ decreased the weight loss observed during adhesion test. Addition of binders ( $2 \mathrm{wt} \%$ poly(vinyl alcohol) and $4 \mathrm{wt} \%$ colloidal alumina) to the milled $\mathrm{Ni} / \mathrm{MgAl}_{2} \mathrm{O}_{4}$ slurry significantly improved the adhesion of the washcoated slurry. Kuan Teo et al. presented a comparative study between two different protocols for the preparation of $\mathrm{Au}$ powder washcoated cordierite monoliths [54]. The $\mathrm{Au} / \mathrm{Fe}_{2} \mathrm{O}_{3}$ based powder catalysts were prepared following three methods, sonochemical, coprecipitation and deposition-precipitation; the washcoated monoliths were prepared by loading the powder catalysts in a one-stage washcoating and in a two-stage washcoating. The Au particle size in powder catalysts prepared by sonochemical method were very $\mathrm{pH}$-sensitive thus an one stage washcoating protocol, at high $\mathrm{pH}$ value (6-8) was developed; the two-stage protocol was used in the washcoating with the catalyst powder prepared by coprecipitation and deposition-precipitation method, in which the catalyst support is first washcoated onto the monolith, followed by the coating of the 2nd layer of the Au powder catalyst. In most cases, the slurry does not contain the active component, therefore a further treatment is necessary to load the metal, such as the impregnation, so a combination of more techniques can be also used to realize structured catalyst. Wójcik et al. used a combination of washcoating and solution combustion synthesis or impregnation to realize $\mathrm{Co}_{3} \mathrm{O}_{4}\left|\alpha-\mathrm{Al}_{2} \mathrm{O}_{3}\right|$ cordierite structured catalysts [58].

\subsection{Coating Stability}

One of the critical aspects in determining the goodness of a coating is the mechanical and thermal resistance of the coated layer [59], since the stability of the coating can have effects on the life of the catalyst and be decisive for the choice in industrial applications. Ultrasound adherence test $[60,61]$ is a technique in which the coated structure is immersed in a non-solvent, such as petroleum ether and submitted to ultrasonication for $30 \mathrm{~min}$. The resistance of the coating is evaluated as the weight loss as function of the time. The Drop test was described by Zapf et al. [62]; the coated catalysts were placed on a guided metal block and were dropped from a distance of $0.5 \mathrm{~m}$ at a speed of $3 \mathrm{~m} / \mathrm{s}$, impinging on a stainless steel plate. The determined weight loss of the coated platelet was used as a reference value for judging adhesion quality. Stefanescu et al. proposed, in addition to the ultrasound test, a thermal shock test in which the sample is treated in a oven from $20^{\circ} \mathrm{C}$ to $800^{\circ} \mathrm{C}$, in order to simulate the start-up and shut-down procedure of an on-board reformer [63]. Agrafiotis and Tsetsekou evaluated the weight loss of the coating exposing the loaded monolith in a hot stream of air in a small laboratory reactor at $800{ }^{\circ} \mathrm{C}$ and at a GHSV of $100,000 \mathrm{~h}^{-1}$ [64]. Ugues et al. evaluated the adhesion properties of the coating by means of vibration tests [65]. Giornelli et al. proposed two adhesion tests, the first was 
carried out by means of a piece of adhesive tape (Scotch $3 \mathrm{M}$ ) stuck onto the surface, in which the tape was firmly rubbed with fingertip and removed. The second test was carried out by introducing the sample in a thermo balance, applying temperature cycles $\left(108^{\circ} \mathrm{C} / \mathrm{min}\right.$ ) under different atmospheres (air, nitrogen, hydrogen). The temperature was held at $200^{\circ} \mathrm{C}$ for $12 \mathrm{~h}$, then decreased to room temperature and again increased up to $500{ }^{\circ} \mathrm{C}(12 \mathrm{~h})$ [28]. Recently Yang et al. proposed a method in which a scrapper is connected to a material testing equipment (Zwick/Roell Z 0.5, Germany) which controls the rate at which the crapper moves and register the force received $[66,67]$. The adhesive strength is calculated as $F_{\text {eff }} /\left(\varepsilon_{\text {eff }} \times W\right)$, where $F_{\text {eff }}$ is the effective force, $\varepsilon_{\text {eff }}$ is the effective displacement and $W$ is the scraper width.

Table 1. Deposited catalytic formulations per coating technique: references.

\begin{tabular}{|c|c|c|c|c|}
\hline Method & Structure & Material & $\begin{array}{l}\text { Deposited Catalytic } \\
\text { Formulation }\end{array}$ & Reference \\
\hline $\begin{array}{c}\text { Solution combustion } \\
\text { synthesis }\end{array}$ & Monolith & $\mathrm{SiC}$ & $\mathrm{LiFeO}_{2}$ & [3] \\
\hline Washcoating & Monolith & FeCrAlloy & $\begin{array}{c}\mathrm{r}-\mathrm{Al}_{2} \mathrm{O}_{3}, \mathrm{CeO}_{2} / \mathrm{Al}_{2} \mathrm{O}_{3} \\
\mathrm{Ce}_{0.9} \mathrm{Eu}_{0.1} \mathrm{O}_{2} / \mathrm{Al}_{2} \mathrm{O}_{3} \\
\mathrm{Pt} / \mathrm{CeO}_{2} / \mathrm{Al}_{2} \mathrm{O}_{3}\end{array}$ & [5] \\
\hline Washcoating & Monolith & Cordierite & $\mathrm{y}-\mathrm{Al}_{2} \mathrm{O}_{3}$ & [6] \\
\hline Washcoating & Foams & Aluminum & $\mathrm{\gamma}-\mathrm{Al}_{2} \mathrm{O}_{3}$ & {$[7]$} \\
\hline Washcoating & Monolith & FeCrAlloy & $\begin{array}{c}\mathrm{Ce}_{0.8} \mathrm{Fe}_{0.2} \mathrm{O}_{2} / \mathrm{Al}_{2} \mathrm{O}_{3} \\
\mathrm{Pt} / \mathrm{Ce}_{0.8} \mathrm{Fe}_{0.2} \mathrm{O}_{2} / \mathrm{Al}_{2} \mathrm{O}_{3} \\
\mathrm{Au} / \mathrm{Ce}_{0.8} \mathrm{Fe}_{0.2} \mathrm{O}_{2} / \mathrm{Al}_{2} \mathrm{O}_{3}\end{array}$ & [11] \\
\hline Impregnation & Monolith & $\mathrm{SiC}$ & $\mathrm{Ni}$ & [23] \\
\hline Washcoating & Monolith & $\mathrm{SiC}$ & $\mathrm{CeO}_{2}-\mathrm{\gamma}-\mathrm{Al}_{2} \mathrm{O}_{3}$ & [23] \\
\hline Impregnation & Monolith & Cordierite & $\mathrm{Mo}(\mathrm{VI}) / \mathrm{ZrO}_{2}$ & {$[24]$} \\
\hline Impregnation & Monolith & $\mathrm{SiC}$ & $\mathrm{Al}_{2} \mathrm{O}_{3}, \mathrm{Co}_{3} \mathrm{O}_{4}$ & {$[25]$} \\
\hline Sol-Gel & Plate & Stainless steel & $\mathrm{VOx} / \mathrm{TiO}_{2}$ & {$[28]$} \\
\hline $\begin{array}{c}\text { Solution combustion } \\
\text { synthesis }\end{array}$ & Monolith & Alumina & $\mathrm{Pd} / \mathrm{Co}_{3} \mathrm{O}_{4}$ & [30] \\
\hline Electrodeposition & Foams & FeCrAlloy & $\mathrm{Ni} / \mathrm{Al}-\mathrm{NO}_{3}$ & {$[31]$} \\
\hline Electrodeposition & Foams & FeCrAlloy & $\mathrm{Pd}-\mathrm{CeO}_{2}$ & {$[32]$} \\
\hline $\begin{array}{c}\text { Electrophoretic } \\
\text { deposition }\end{array}$ & Foams & $\mathrm{Al}_{2} \mathrm{O}_{3}-\mathrm{C}$ & $\mathrm{Al}_{2} \mathrm{O}_{3}$ & [35] \\
\hline Electroless deposition & Plate & Aluminum & $\mathrm{Cu}-\mathrm{Zn}$ & {$[36]$} \\
\hline Electroless deposition & Plate & Aluminum & $\begin{array}{l}\mathrm{Cu}-\mathrm{Ni} / \mathrm{Zn}, \mathrm{Cu}-\mathrm{Co} / \mathrm{Zn}, \\
\mathrm{Cu}-\mathrm{Sn} / \mathrm{Zn}, \mathrm{Cu}-\mathrm{Fe} / \mathrm{Zn}\end{array}$ & [37] \\
\hline $\begin{array}{l}\text { Chemical vapor } \\
\text { deposition (CVD) }\end{array}$ & Foils & Aluminum & $\mathrm{Fe}$ & [40] \\
\hline $\begin{array}{l}\text { Chemical vapor } \\
\text { deposition (CVD) }\end{array}$ & Monolith & Cordierite & $\mathrm{Fe}$ & [41] \\
\hline $\begin{array}{c}\text { Atomic layer } \\
\text { deposition (ALD) }\end{array}$ & Monolith & Alumina & $\mathrm{ZnO}$ & [43] \\
\hline $\begin{array}{c}\text { Chemical conversion } \\
\text { coating }\end{array}$ & Foams & Aluminum & $\mathrm{CeO}_{2}$ & [47] \\
\hline Washcoating & Monolith & Alumina & $\mathrm{r}-\mathrm{Al}_{2} \mathrm{O}_{3}$ & {$[49]$} \\
\hline Washcoating & Monolith & Cordierite & $\mathrm{CeO}_{2}$ & [50] \\
\hline
\end{tabular}


Table 1. Cont.

\begin{tabular}{|c|c|c|c|c|}
\hline Method & Structure & Material & $\begin{array}{l}\text { Deposited Catalytic } \\
\text { Formulation }\end{array}$ & Reference \\
\hline Washcoating & Foams & Aluminum & $\mathrm{x}-\mathrm{Al}_{2} \mathrm{O}_{3}$ & [51] \\
\hline Washcoating & Monolith & Aluminum & $\mathrm{r}-\mathrm{Al}_{2} \mathrm{O}_{3}$ & [51] \\
\hline Washcoating & Foams & Aluminum & $\mathrm{\gamma}-\mathrm{Al}_{2} \mathrm{O}_{3}$ & [52] \\
\hline Washcoating & Monolith & Cordierite & $\mathrm{Au} / \alpha-\mathrm{Fe}_{2} \mathrm{O}_{3}$ & [54] \\
\hline Washcoating & Microchannels & Stainless steel & $\mathrm{x}-\mathrm{Al}_{2} \mathrm{O}_{3}$ & [55] \\
\hline Washcoating & Monolith & FeCrAlloy & $\mathrm{x}-\mathrm{Al}_{2} \mathrm{O}_{3}, \mathrm{Ni} / \mathrm{MgAl}_{2} \mathrm{O}_{4}$ & [57] \\
\hline $\begin{array}{l}\text { Solution combustion } \\
\text { synthesis }\end{array}$ & Monolith & $\alpha-\mathrm{Al}_{2} \mathrm{O}_{3} /$ Cordierite & $\mathrm{Co}_{3} \mathrm{O}_{4}$ & [58] \\
\hline Washcoating & Monolith & Cordierite & $\alpha-\mathrm{Al}_{2} \mathrm{O}_{3}$ & [58] \\
\hline Washcoating & Monolith & FeCrAlloy & SBA-15 & [61] \\
\hline Washcoating & Microchannels & Stainless steel & $\begin{array}{c}\mathrm{r}-\mathrm{Al}_{2} \mathrm{O}_{3}, \mathrm{Pt} / \mathrm{Al}_{2} \mathrm{O}_{3} \\
\mathrm{Rh} / \mathrm{Al}_{2} \mathrm{O}_{3}\end{array}$ & [62] \\
\hline Washcoating & Monolith & Cordierite & $\mathrm{x}-\mathrm{Al}_{2} \mathrm{O}_{3}$ & [64] \\
\hline
\end{tabular}

\section{Activity and Kinetics of Structured Catalysts in WGS Reaction}

In a process intensification view, the investigation of the issues related to reactor design and kinetics appears crucial. In this regard, the advantages of monolithic as well as micro structured reactors have been shown in comparison with the commonly used configurations (packed bed catalysts) [68].

For WGS process, the development of innovative catalysts is mainly devoted to the achievement of higher $\mathrm{CO}$ conversions in the range $250-350{ }^{\circ} \mathrm{C}$, which are quite low in conventional reactors due to the slow kinetics. Compared to the CuZn catalysts, industrially selected for low-temperature WGS, ceria-based catalysts are highly active and non-pyrophoric [69]. In this regard, for $\mathrm{CeO}_{2}$-based catalysts supported on alumina foam monoliths, it was shown that $\mathrm{Ni}$ and $\mathrm{Ru}$ displayed almost the same activity while for the other noble metals the performance followed the order $\mathrm{Pt}>\mathrm{Rh}>\mathrm{Pd}$ (Figure 5). However, under the selected operative conditions, CO conversion close to equilibrium values was only reached above $450^{\circ} \mathrm{C}$ on the most promising formulations and, at lower temperature, the performance still remains unsatisfactory [49]. In fact, beside the active species choice, the selection of operative conditions (i.e., contact time and feeding conditions) may strongly affect the activity of the structured catalysts for water gas shift reaction. For example, Quiney et al. [70] found that the performance of a $\mathrm{Pt} / \mathrm{CeO}_{2} / \mathrm{Al}_{2} \mathrm{O}_{3}$ catalyst supported on a stainless steel monolith can be enhanced by changing the space velocity from 1.21 to $4.84 \mathrm{~kg} \cdot \mathrm{s} \cdot \mathrm{mol}^{-1}$ and feeding conditions from $\mathrm{CO} / \mathrm{H}_{2} \mathrm{O}=1 / 2.6$ to $\mathrm{CO} / \mathrm{H}_{2} \mathrm{O}=1 / 10.6$ : the CO conversion increased more than $20 \%$ at $200{ }^{\circ} \mathrm{C}$ and reached the maximum value of $90 \%$ at $260^{\circ} \mathrm{C}$. Conversely, by reducing the contact time, higher temperatures (above $350^{\circ} \mathrm{C}$ ) are required to observe significant improvements in $\mathrm{CO}$ conversion (Figure 6). Ruettinger et al. [71] investigated the performance of a noble metal based monolith between 180 and $400{ }^{\circ} \mathrm{C}$, finding a conversion higher than $50 \%$ between 230 and $280{ }^{\circ} \mathrm{C}$ for a contact time of almost $280 \mathrm{~ms}$ and a $\mathrm{CO} / \mathrm{H}_{2} \mathrm{O}=8.6$. Moreover, due to the choice of specific inhibitors, the contribution of methanation side reaction was negligible below $280{ }^{\circ} \mathrm{C}$, with a maximum concentration of $\mathrm{CH}_{4}$ of almost $500 \mathrm{ppm}$ above $320^{\circ} \mathrm{C}$. Such catalysts appear very promising for fuel processor applications, allowing small reactor volume, low pressure drops and high mechanical properties. 


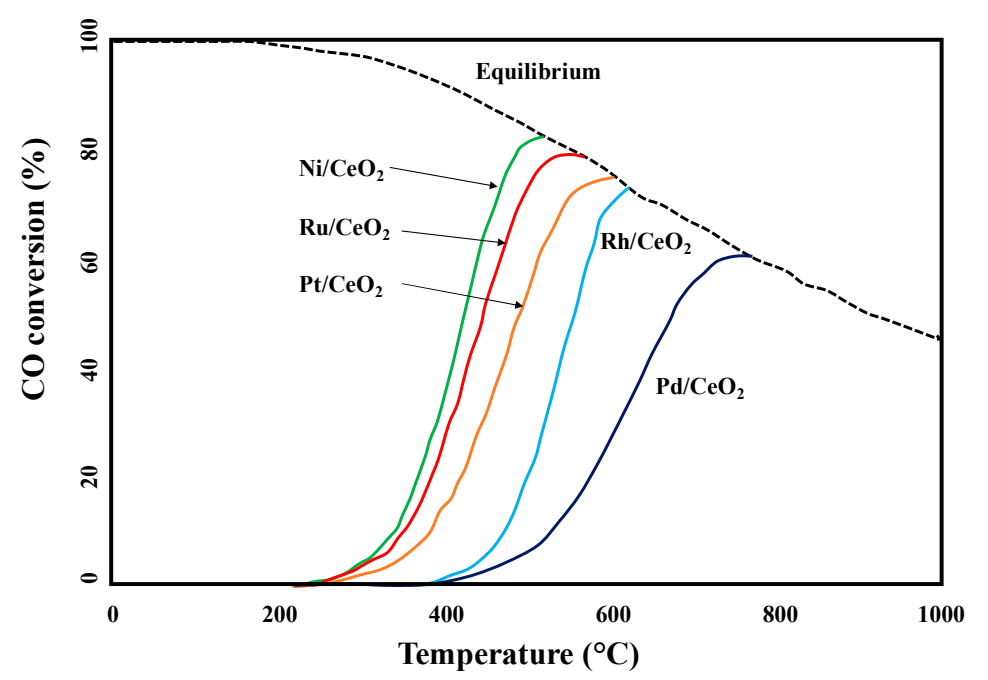

Figure 5. $\mathrm{CO}$ conversion as a function of reaction temperature over $\mathrm{CeO}_{2}$-based catalysts supported on alumina foam monoliths [49], $\mathrm{CO} / \mathrm{H}_{2} \mathrm{O}=1 / 4$; tc $=17 \mathrm{~ms}$.

A Pt-Re catalysts supported on $\mathrm{CeZrO} / 4 / \mathrm{Al}_{2} \mathrm{O}_{3}$ and deposited on aluminium foam well approached the equilibrium $\mathrm{CO}$ conversion above $280{ }^{\circ} \mathrm{C}$, with a mean conversion of almost $40 \%$ recorded at $220^{\circ} \mathrm{C}\left(\mathrm{CO} / \mathrm{H}_{2} \mathrm{O}=1 / 3.75, \mathrm{tc}=180 \mathrm{~ms}\right)$ [52]; the structured catalyst also displayed a remarkable higher activity compared to a powder catalyst having the same formulation. In fact, the choice of aluminium as structured carrier, due to its high thermal conductivity, allowed a back diffusion of the heat along the catalytic bed: An increase of the temperature in the inlet catalyst section and a less pronounced increase of the temperature in the outlet catalyst section were observed, with a reduced temperature gradient between inlet and outlet sections compared to powder catalyst. As a result, a good approach to $\mathrm{CO}$ equilibrium conversion was observed even at low temperatures.

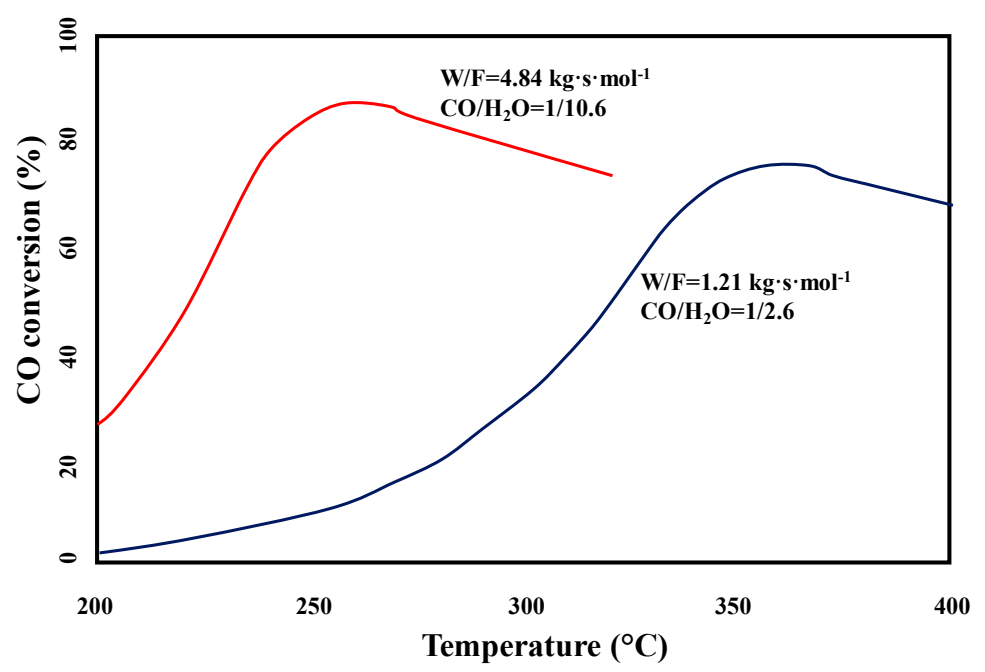

Figure 6. Activity of a Pt/CeO $2 / \mathrm{Al}_{2} \mathrm{O}_{3}$ catalyst deposited on a stainless steel-monolith [70].

Kuan Teo et al. reported the preparation and the evaluation in WGS reaction, of structured catalysts obtained by washcoating $\mathrm{Au} / \mathrm{Fe}_{2} \mathrm{O}_{3}$ based powder catalysts onto cordierite structures [54]. The results highlighted the high activity and the low stability of these catalysts, however the doping with $\mathrm{ZrO}_{2}$ provided a much higher stability. Özyönüm et al. reported the activity of micro structured catalysts by washcoating cordierite monoliths with colloidal ceria followed by deposition of Au-Re catalytic formulation by homogeneous deposition-precipitation method [50]. The results highlighted 
the effect of Re as promoter, in increasing the activity of the catalysts. A comparative study between two structured catalysts prepared by washcoating aluminum foams, with two different catalytic formulation was also reported [72], highlighting the role of the support. Ceria-based washcoated foam catalyst showed much higher activity with respect to the zirconia-based washcoated foam catalyst; the different activity was explained as the result of the high reducibility of ceria support, due to the extreme mobility of the oxygen in the lattice of the ceria support. An interesting comparison between structured gold and platinum noble metals supported on iron-doped ceria mixed oxide for $\mathrm{O}_{2}$-assisted WGS was reported by González-Castaño et al. [11]. Both monoliths and powders catalysts showed good activity in WGS reaction, being $\mathrm{Pt}$ superior to Au in all cases. The scaling up from the powder to the structured catalysts seemed to affect mainly the gold-based catalyst while the Pt monolith retains its excellent behaviour. $\mathrm{O}_{2}$ addition boosted the WGS activity for Au-based monolith catalyst. The higher $\mathrm{CO}$ conversion, observed for the Pt-based monolith, was attributed to the parallel CO oxidation reaction. Routinely, it has assumed that the catalytic layer coated on monoliths and microchannel reactors preserve the same properties of the initial powder catalyst; however, Bobadilla et al. have denied this affirmation [68].

The study revealed that during the preparation of the slurry the powder catalyst used suffered for a redispersion of the metal, demonstrating that the active layer of the structured catalysts cannot be simple considered as equivalent to the corresponding powder catalyst.

Table 2 provides a comparison between the performance of different structured catalysts for water gas shift reaction, reported in terms of $\mathrm{CO}$ conversion at two temperatures ( 300 and $200{ }^{\circ} \mathrm{C}$ ). The results revealed that $\mathrm{Al}_{2} \mathrm{O}_{3}$ addition to the washcoat is beneficial in order to improve catalyst activity. Moreover, metallic carriers showed superior performance for WGS reaction compared to cordierite supports, due to their higher thermal conductivity. Among the selected active species, platinum and the combination platinum-rhenium allowed the best activity, with $\mathrm{CO}$ conversion close to $100 \%$ at $300{ }^{\circ} \mathrm{C}$ over the $\mathrm{Pt}-\mathrm{Re} / \mathrm{CeZrO}{ }_{4} / \mathrm{Al}_{2} \mathrm{O}_{3}, \mathrm{Pt}-\mathrm{Re} / \mathrm{CeO}_{2} / \mathrm{Al}_{2} \mathrm{O}_{3}$ and $\mathrm{Pt} / \mathrm{Ce}_{0.8} \mathrm{Fe}_{0.2} \mathrm{O}_{2} / \mathrm{Al}_{2} \mathrm{O}_{3}$ catalysts. In addition, the Pt-Re catalyst showed satisfactory performance even at $200{ }^{\circ} \mathrm{C}$, despite tested under quite severe operative conditions (low steam to $\mathrm{CO}$ ratio and high space velocity).In addition, the use of structured catalysts was found to be very helpful for the study of intrinsic kinetics when the involved reactions are very fast, due to the presence of thin films of catalysts on the reactor channels walls [73]. Some examples related to the evaluation of WGS kinetics over structured catalysts are reported below.

Tonkovich et al. [74] studied the performance of a $\mathrm{Ru} / \mathrm{ZrO}_{2}$ catalyst in a power form as well as supported on nickel foam monolith carriers, able to retain the high activity of the noble metal-based catalyst and assuring reduced pressure drops. Fast intrinsic kinetics were observed over the engineered-monolithic catalyst, displaying almost $100 \%$ selectivity to carbon dioxide and hydrogen even at very low contact time $(10 \mathrm{~ms})$, thus overcoming the thermodynamic predicted values at $500{ }^{\circ} \mathrm{C}$. The formation of the undesired product (methane) can be avoided in the microchannel reactor due to the exploitation of millisecond reaction times. The very fast kinetics of microchannel reactors are ascribable to the improved heat and mass transport rates which paves the way for smaller, modular and less expensive reactors readily exploitable in fuel processing systems. Similarly, it was shown [75] that micro structured reactors using a $\mathrm{Ru} / \mathrm{ZrO}_{2}$ catalyst display a reduction of $\mathrm{CO}$ content in the reaction mixture of almost $95 \%$ at $250-300{ }^{\circ} \mathrm{C}$ even at $30 \mathrm{~ms}$. Germani and Schuurman [76] investigated the activity of micro structured $\mathrm{Pt} / \mathrm{CeO}_{2} / \mathrm{Al}_{2} \mathrm{O}_{3}$ catalysts (prepared by depositing the catalyst in the microchannels of stainless steel platelets) between 250 and $400{ }^{\circ} \mathrm{C}$ and carried out kinetic experiments assuring plug flow conditions as well as no mass and heat transfer limitations (for this purpose, long platelets are more effective than a stack of short platelets). They found a kinetic expression where the reaction order of carbon monoxide is close to zero, which indicates that adsorption sites of carbon monoxide are saturated. Moreover, hydrogen inhibits the reaction to a higher extent compared to carbon dioxide. In addition, the experimental data were best fitted by a model based on a dual-site mechanism, where the rate-determining step involves $\mathrm{CO}_{2}$, adsorbed on platinum, and $\mathrm{H}_{2} \mathrm{O}$, dissociatively chemisorbed on $\mathrm{CeO}_{2}$, which react to form an intermediate carboxyl 
species. The latter species reacts with a hydroxyl group on a free platinum site, yielding $\mathrm{CO}_{2}$ and $\mathrm{H}_{2} \mathrm{O}$. Ceria, in fact, was found to reduce the activation energy of water, promoting its decomposition to hydrogen [77]. A kinetic analysis of the WGS reaction was also performed over a $\mathrm{Pt} / \mathrm{CeO}_{2} / \mathrm{Al}_{2} \mathrm{O}_{3}$ catalyst supported on a metallic (FeCr Alloy stainless steel) micro monolith [13]; in the latter case, the catalyst was promoted by a Zr-based ionic conductor. Catalytic experiments were performed between 200 and $400{ }^{\circ} \mathrm{C}$; isothermal conditions through the monolith were verified within a very low error $\left(4{ }^{\circ} \mathrm{C}\right)$, which is ascribable to the high thermal conductivity of the support. Moreover, mass internal diffusion can be ignored due to the very thin catalytic layer ( $<20$ micron). An integral reactor approach analysis was selected and the expression of the rate (Equation $(2),-r_{\mathrm{CO}}$ ) was in accordance with the equations reported in the literature for Pt-based catalysts [78,79].

$$
-r_{\mathrm{CO}}=D_{i} \cdot \sigma_{\mathrm{CO}} \cdot \frac{k \cdot P_{H 2 O}^{\beta} \cdot(1-\eta)}{1+A P_{H 2}^{\alpha}}
$$

$D i$ is a parameter related to catalyst deactivation, $\sigma_{C O}$ is a correction factor related to $C O$ conversion, $k$ is the kinetic constant evaluated at a reference temperature To, $\eta$ is the reversibility factor (ranging between 0 and 1), Pi the partial pressures (in $\mathrm{Pa}$ ) and $A$ the hydrogen adsorption constant. In the proposed rate expression, the influence of $\mathrm{CO}$ partial pressure is negligible while the promoting effect of water and the negative role of hydrogen were highlighted. Table 3 lists the calculated kinetic parameters for the proposed reaction rate expression. The estimated reaction order for water $(\beta)$ is very low compared to the values found in the literature [80]. In fact, the available ionic conductors improve water dissociation, providing a higher concentration of $\mathrm{OH}$ next to the $\mathrm{CO}$ molecules, which enhances the water activation step.

In addition, it is worthwhile noting that the pre-exponential factor in the case of the structured catalyst is larger than that measured for the powders by a factor of 2.5, which demonstrates the higher initial activity of the monolith. The results of the kinetic study were used to design a water gas shift reactor: due to the drop of catalyst activity below $250^{\circ} \mathrm{C}$, a single stage adiabatic reactor may have a too large volume. Conversely, the optimal configuration was based on a two-stage adiabatic reactor with additional water injection and working according to the optimal temperature path [70]. An easier kinetic expression was found by Palma et al. for WGS reaction between 150 and $350{ }^{\circ} \mathrm{C}$ over Pt-Re/CeZrO catalysts supported on aluminium foams with a washcoat of alumina: a first order rate equation well fitted the experimental data, with an activation energy of $49.8 \mathrm{~kJ} \cdot \mathrm{mol}^{-1}$ [81]. In the latter catalytic system, as described above, due to the heat redistribution along the catalytic bed, inlet temperature increased, thus favouring reaction kinetics, while outlet temperature decreased, with a significant improvement in the thermodynamics: therefore, it was possible to design a reactor operating in a single stage under adiabatic conditions. A kinetic expression consistent with an elementary reaction being first order in all the species was also found by Wheeler et al. [49], which investigated water gas shift reaction over $\mathrm{M} / \mathrm{CeO}_{2}$ catalysts $(\mathrm{M}=\mathrm{Ru}, \mathrm{Ni}, \mathrm{Rh}, \mathrm{Pt}, \mathrm{Pd})$ supported on alumina foam monoliths. However, higher activation energies (ranging from 80 to $130 \mathrm{~kJ} \cdot \mathrm{mol}^{-1}$ ) were observed on the latter systems compared to the $\mathrm{Pt}-\mathrm{Re} / \mathrm{CeZrO} 4$ catalysts (Table 4). 
Table 2. Activity of different WGS structured catalysts.

\begin{tabular}{|c|c|c|c|c|}
\hline Structured Catalyst & $\begin{array}{l}\text { Operative } \\
\text { Conditions }\end{array}$ & $\begin{array}{l}\text { CO Conversion } \\
\text { at } 300{ }^{\circ} \mathrm{C}(\%)\end{array}$ & $\begin{array}{l}\text { CO Conversion } \\
\text { at } 200^{\circ} \mathrm{C}(\%)\end{array}$ & Ref. \\
\hline $\begin{array}{l}\mathrm{Pt} / \mathrm{Ce}_{0.8} \mathrm{Fe}_{0.2} \mathrm{O}_{2} / \mathrm{Al}_{2} \mathrm{O}_{3} \text { supported } \\
\text { on metallic monolith }\end{array}$ & $\begin{array}{l}\mathrm{CO} / \mathrm{H}_{2} \mathrm{O}=6.7 \\
900 \mathrm{~ms}\end{array}$ & 99 & 55 & [11] \\
\hline $\begin{array}{c}\mathrm{Au} / \mathrm{Ce}_{0.8} \mathrm{Fe}_{0.2} \mathrm{O}_{2} / \mathrm{Al}_{2} \mathrm{O}_{3} \\
\text { supported on metallic monolith }\end{array}$ & $\begin{array}{l}\mathrm{CO} / \mathrm{H}_{2} \mathrm{O}=6.7 \\
900 \mathrm{~ms}\end{array}$ & 81 & 32 & [11] \\
\hline $\begin{array}{l}\mathrm{M} / \mathrm{CeO}_{2} \text { supported on alumina } \\
\text { foam monoliths }\end{array}$ & \multirow{6}{*}{$\begin{array}{l}\mathrm{CO} / \mathrm{H}_{2} \mathrm{O}=1 / 4 \\
17 \mathrm{~ms}\end{array}$} & & & \multirow{6}{*}{ [49] } \\
\hline $\mathrm{Ru} / \mathrm{CeO}_{2}$ & & 8 & 0 & \\
\hline $\mathrm{Ni} / \mathrm{CeO}_{22}$ & & 10 & 0 & \\
\hline $\mathrm{Rh} / \mathrm{CeO}_{2}$ & & 0 & 0 & \\
\hline $\mathrm{Pd} / \mathrm{CeO}_{2}$ & & 0 & 0 & \\
\hline $\mathrm{Pt} / \mathrm{CeO}_{2}$ & & 5 & 0 & \\
\hline $\begin{array}{c}\mathrm{Pt}-\mathrm{Re} / \mathrm{CeZrO} \mathrm{Cr}_{4} / \mathrm{Al}_{2} \mathrm{O}_{3} \text { supported } \\
\text { on aluminium foam }\end{array}$ & $\begin{array}{c}\mathrm{CO} / \mathrm{H}_{2} \mathrm{O}=1 / 3.75 \\
180 \mathrm{~ms}\end{array}$ & 92 & - & [52] \\
\hline $\begin{array}{c}\mathrm{Pt}-\mathrm{Re} / \mathrm{CeZrO}_{4} / \mathrm{Al}_{2} \mathrm{O}_{3} \text { supported } \\
\text { on aluminium foam }\end{array}$ & $\begin{array}{c}\mathrm{CO} / \mathrm{H}_{2} \mathrm{O}=1 / 3.75 \\
360 \mathrm{~ms}\end{array}$ & 98 & 40 & [52] \\
\hline $\begin{array}{c}\mathrm{Au} / \mathrm{Fe}_{2} \mathrm{O}_{3} \cdot \mathrm{ZrO}_{2} \text { supported on } \\
\text { cordierite foam }\end{array}$ & $\begin{array}{c}\mathrm{CO} / \mathrm{H}_{2} \mathrm{O}=1 / 17.1 \\
4 \mathrm{~s}\end{array}$ & - & 93 & [54] \\
\hline $\begin{array}{c}\mathrm{Au} / \mathrm{Fe}_{2} \mathrm{O}_{3} \cdot \mathrm{ZrO}_{2} \text { supported on } \\
\text { cordierite foam }\end{array}$ & $\begin{array}{c}\mathrm{CO} / \mathrm{H}_{2} \mathrm{O}=1 / 17.1 \\
436 \mathrm{~ms}\end{array}$ & - & 40 & [54] \\
\hline $\begin{array}{l}\mathrm{Pt} / \mathrm{CeO}_{2} / \mathrm{Al}_{2} \mathrm{O}_{3} \text { supported on } \\
\text { stainless steel monoliths }\end{array}$ & $\begin{array}{l}\mathrm{CO} / \mathrm{H}_{2} \mathrm{O}=1 / 10.6 \\
56 \mathrm{~ms}\end{array}$ & 70 & 30 & [70] \\
\hline $\begin{array}{c}\mathrm{Pt} / \mathrm{CeO}_{2} / \mathrm{Al}_{2} \mathrm{O}_{3} \text { supported on } \\
\text { stainless steel monoliths }\end{array}$ & $\begin{array}{l}\mathrm{CO} / \mathrm{H}_{2} \mathrm{O}=1 / 2.6 \\
25 \mathrm{~ms}\end{array}$ & 30 & 0 & [70] \\
\hline PM(1.5x)+promoter/support & $\begin{array}{l}\mathrm{CO} / \mathrm{H}_{2} \mathrm{O}=1 / 8.6 \\
280 \mathrm{~ms}\end{array}$ & 80 & 30 & [71] \\
\hline $\begin{array}{l}\mathrm{Au}-\mathrm{Re} / \mathrm{CeO}_{2} \text { supported on } \\
\text { cordierite foam }\end{array}$ & $\begin{array}{c}\mathrm{CO} / \mathrm{H}_{2} \mathrm{O}=1 / 3 \\
150\end{array}$ & 68 & - & [71] \\
\hline $\begin{array}{c}\mathrm{Pt}-\mathrm{Re} / \mathrm{CeO}_{2} / \mathrm{Al}_{2} \mathrm{O}_{3} \text { supported on } \\
\text { aluminium foam }\end{array}$ & $\begin{array}{l}\mathrm{CO} / \mathrm{H}_{2} \mathrm{O}=3.75 \\
360 \mathrm{~ms}\end{array}$ & 98 & 30 & [72] \\
\hline $\begin{array}{c}\mathrm{Pt}-\mathrm{Re} / \mathrm{ZrO}_{2} / \mathrm{Al}_{2} \mathrm{O}_{3} \text { supported on } \\
\text { aluminium foam }\end{array}$ & $\begin{array}{l}\mathrm{CO} / \mathrm{H}_{2} \mathrm{O}=3.75 \\
360 \mathrm{~ms}\end{array}$ & 50 & - & [72] \\
\hline
\end{tabular}

Table 3. Parameters of the rate expression (Equation (2)) for the $\mathrm{Pt} / \mathrm{CeO}_{2} / \mathrm{Al}_{2} \mathrm{O}_{3}$ structured catalyst [13].

\begin{tabular}{cc}
\hline $\mathbf{k}_{\mathbf{0}}$ & $2.08 \times 10^{-7}$ \\
$\mathbf{A}$ & 0.052 \\
$\mathbf{E a}\left(\mathbf{k J} \cdot \mathbf{m o l}^{-\mathbf{1}}\right)$ & 67.40 \\
$\mathbf{T}_{\mathbf{0}} \mathbf{( K )}$ & 473.15 \\
$\boldsymbol{\beta}$ & 0.359 \\
$\boldsymbol{\alpha}$ & 0.428 \\
\hline
\end{tabular}


Table 4. Activation energies of different WGS structured catalysts.

\begin{tabular}{|c|c|c|c|c|}
\hline Structured Catalyst & $\begin{array}{l}\text { Operative } \\
\text { Conditions }\end{array}$ & $\begin{array}{c}\text { Kinetic } \\
\text { Expression Type }\end{array}$ & $\begin{array}{l}\text { Activation Energy } \\
\qquad\left(\mathrm{kJ} \cdot \mathrm{mol}^{-1}\right)\end{array}$ & Ref. \\
\hline $\begin{array}{l}\mathrm{M} / \mathrm{CeO}_{2} \text { supported on alumina } \\
\text { foam monoliths }\end{array}$ & \multirow{6}{*}{$\begin{array}{l}300-1000{ }^{\circ} \mathrm{C} \\
8-50 \mathrm{~ms}\end{array}$} & \multirow{6}{*}{ Power-law } & & \multirow{6}{*}{ [49] } \\
\hline $\mathrm{Ru} / \mathrm{CeO}_{2}$ & & & 80 & \\
\hline $\mathrm{Ni} / \mathrm{CeO}_{22}$ & & & 85 & \\
\hline $\mathrm{Rh} / \mathrm{CeO}_{2}$ & & & 130 & \\
\hline $\mathrm{Pd} / \mathrm{CeO}_{2}$ & & & 100 & \\
\hline $\mathrm{Pt} / \mathrm{CeO}_{2}$ & & & 80 & \\
\hline $\begin{array}{c}\mathrm{Pt}-\mathrm{Re} / \mathrm{CeZrO}_{4} / \mathrm{Al}_{2} \mathrm{O}_{3} \text { supported } \\
\text { on aluminium foam }\end{array}$ & $\begin{array}{l}150-350{ }^{\circ} \mathrm{C} \\
180 \mathrm{~ms}\end{array}$ & Power-low & 49.8 & [52] \\
\hline $\begin{array}{c}\mathrm{Pt} / \mathrm{CeO}_{2} / \mathrm{Al}_{2} \mathrm{O}_{3} \text { supported on a } \\
\text { metallic micromonolith and } \\
\text { promoted by ionic conductors }\end{array}$ & $\begin{array}{l}175-400{ }^{\circ} \mathrm{C} \\
45 \mathrm{~ms}\end{array}$ & Langmuir-Hinshelwood & 67.4 & [76] \\
\hline
\end{tabular}

\section{Process and Modelling}

In the recent years, due to a literature lack of engineering correlations related to the heat and mass transfer properties of structured catalysts, an extensive research effort has been made in this topic, aimed to a full comprehension and description of the transport phenomena occurring in their application in catalytic processes [82,83]. Leading to this focus have been the numerous possible theoretical advantages gainable with the application of structured catalysts; indeed, their application represents an interesting opportunity for strongly exothermic or endothermic processes, due to the efficient heat conductive mechanism and optimal interphase mass transfer characteristics of these structures. Moreover, compared to the conventional packed bed of catalyst pellets, lower pressure drops, and potentially smaller reactor sizes can be obtained with the use of structured catalysts [8].

All the theoretical studies regarding the structured catalysts modelling taken in account in this review are summarized in Table 5.

In 2013, Bianchi et al. [83] analysed the heat transfer in a single-phase reactor packed with two types of open-cell metal foams with very different thermal conductivity, FeCrAlY and aluminum, both characterized by porosities in the range of $95-98 \%$ and pore densities from 10 to 40 PPI. During the experiments, $\mathrm{He}$ (high thermal conductivity) or $\mathrm{N}_{2}$ (low thermal conductivity) have been used as feeding gas, and two operating modes, heating and cooling were analysed with the aim of representing both exothermic and endothermic processes. The radial temperature profile along the foam bed and the axial temperature profile of the gas stream were measured, during the tests, with several thermocouples placed in different positions. The aim of the study was to find a correlation for the wall heat transfer coefficient using a 2D pseudo-homogeneous heat transfer model based on the collected experimental data and establish its dependence by the process conditions and the foam structural properties. The results showed a proportional dependence of the wall heat transfer coefficient by the gas conductivity and the foam pore density, leading to the conclusion of the dominant conductive mechanism in the analysed conditions. Withal, Bianchi et al. [84] developed also a 3D model based on two different aluminium open-cell foams, scanned by X-ray micro-computed tomography, in the interest of estimating the overall heat transfer coefficients for four different configurations of the foam bed and the reactor wall coupling (thermal continuity, adiabatic boundary conditions, gap of $100 \mu \mathrm{m}$ and gap of $1 \mathrm{~mm}$ ). The model pointed out what was already expected by the authors, indeed, when the solid conduction was the limiting factor in heat transfer, thermal discontinuity was preferred, while when convection through the fluid phase was the dominant resistance to heat transfer, a gap between the foam and the reactor wall worsens the heat transport. This study also led to obtain correlations for the wall heat transfer coefficient. Moreover, Computational Fluid Dynamics (CFD) 
modelling, based on the open-source finite volume code OpenFOAM ${ }^{\circledR}$, has been used by A. Della Torre et al. [85] for the simulation of catalytic CO combustion over $\gamma$-alumina open-cell foams washcoated by palladium oxide, estimating the model parameters on the basis of the experimentally values founded in literature. The model, consisting of a finite volume (FV) solver for the description of fluid-dynamic and chemistry phenomena in the fluid phase and, a finite area (FA) solver for the representation of the catalytic phenomena occurring on the washcoat surface, has been tested under two conditions: a plate-type reactor in which the $\mathrm{CO}$ conversion limiting factor was the chemical reaction and a foam reactor screened at higher temperatures, in order to have a $\mathrm{CO}$ conversion limited by the diffusion of the reactants from the gas phase to the washcoat. The study results showed that the implemented model was able to describe the conversion under both kinetic and diffusion-controlled regimes. Furthermore, Bracconi et al. [86,87] investigated heat and mass transfer of virtually reconstructed foams utilizing CFD simulations, aiming to appreciate the foam geometry influence on the transport phenomena. As concern heat transfer, the conduction in the solid matrix resulted to be the main contribution, leading to high heat transfer rates gained by the interconnected solid matrix, while an increase in the porosity worsens the heat conduction. Another exanimated aspect has been the influence of the ratio between the node and strut diameters that showed a lower thermal conduction in the case of a minor strut cross-sectional area at constant void fraction. Moreover, investigation by numerical simulations of mass transfer through virtually reconstructed foams exhibited a strong dependence of the mass transfer coefficients by the porosity, showing an empirical dependence on the inverse of the square of the void fraction. Indeed, a correlation of Sherwood number as a function of Reynolds and Schmidt numbers, based on numerical simulations and experimental tests, has been found to be the best representation of the external mass transfer:

$$
h_{d_{s, a v g}}=\varepsilon^{-2}\left(0.566 R e_{d_{s, a v g}}^{0.33}+0.039 R e_{d_{s, a v g}}^{0.8}\right) S c^{1 / 3}
$$

With the aim of evaluating the foam geometry influence on transport phenomena, also Ambrosetti et al. [88] developed a model for the estimation of the specific surface area of open-cell foams as a function of either cell diameter and porosity or pore diameter and porosity. Deep comprehension of heat and mass transport phenomena could be also useful in process intensification of exothermic equilibrium reactions, such as WGS processes, in which, a heat redistribution along the catalytic bed, would allow reducing both kinetic limitations at the bed inlet, and thermodynamic limitations at its outlet [89]. Palma et al. [89], through a discretized mathematical model, described the solid and gas temperature profiles of four types of open-cell foams, characterized by almost the same void fraction but different PPI values, in order to evaluate if the tortuosity of the material positively affects the heat transfer. Among all the modelled foams, 100\% alumina and aluminum foams showed the flattest temperature profiles, mainly dependent by their higher value of thermal conductivity. The solid and gas temperatures values, obtained for an oven temperature of $400{ }^{\circ} \mathrm{C}$ and $\mathrm{N}_{2}$ total flow rate of $2.4 \mathrm{~N} \mathrm{dm}^{3} / \mathrm{min}$, pointed out that, while in all the cases a higher temperature was reached for the aluminium foam, due to its higher thermal conductivity, the elevated value of porosity of the $100 \%$ alumina foam had a positive effect on the inlet temperature of the gas phase. 
Table 5. Modelling studies concerning structured catalysts.

\begin{tabular}{|c|c|c|c|}
\hline Catalyst & Aim of the Study & Model Type & Reference \\
\hline $\begin{array}{l}\text { Two } \mathrm{Pt} / \mathrm{CeO}_{2} / \mathrm{Al}_{2} \mathrm{O}_{3} \text { based } \\
\text { structured catalysts } \\
\text { supported on a flow-through } \\
\text { aluminum monolith and an } \\
\text { open-cell aluminum foam }\end{array}$ & $\begin{array}{l}\text { Comparative study between } \\
\text { monoliths and foams as } \\
\text { carriers for the WGS reaction }\end{array}$ & $\begin{array}{l}\text { CFD simulation through } \\
\text { COMSOL Multiphysics }{ }^{\circledR}\end{array}$ & [51] \\
\hline $\begin{array}{l}\mathrm{Pt} / \mathrm{Re} \text { based catalyst } \\
\text { supported on } \mathrm{CeZrO}_{4}\end{array}$ & $\begin{array}{l}\text { Comparison between } \\
\text { structured catalyst and } \\
\text { powder catalyst for the } \\
\text { WGS reaction }\end{array}$ & $\begin{array}{l}\text { Computational Fluid } \\
\text { Dynamics (CFD) } \\
\text { modelling }\end{array}$ & {$[52]$} \\
\hline $\begin{array}{l}\text { A powder catalyst and a } \\
\text { structured foam }\end{array}$ & $\begin{array}{c}\text { Study of WGS single stage } \\
\text { process in adiabatic } \\
\text { condition. }\end{array}$ & $\begin{array}{l}\text { CFD modelling with the } \\
\text { use of COMSOL } \\
\text { Multiphysics } 5.0^{\circledR}\end{array}$ & {$[80]$} \\
\hline $\begin{array}{c}\text { Two types of open-cell metal } \\
\text { foams: FeCrAlY and } \\
\text { aluminum }\end{array}$ & $\begin{array}{l}\text { Find a correlation for the } \\
\text { wall heat transfer model }\end{array}$ & $\begin{array}{l}\text { 2D pseudo-homogeneous } \\
\text { heat transfer model }\end{array}$ & [83] \\
\hline Aluminium open-cell foams & $\begin{array}{l}\text { Estimation of the heat } \\
\text { transfer coefficients for } \\
\text { different reactor's } \\
\text { configurations }\end{array}$ & $\begin{array}{l}\text { 3D model coupled with } \\
\text { X-ray micro-computed } \\
\text { tomography }\end{array}$ & [84] \\
\hline $\begin{array}{c}\gamma \text {-alumina open-cell foams } \\
\text { washcoated by } \\
\text { palladium oxide }\end{array}$ & $\begin{array}{l}\text { Simulation of catalytic CO } \\
\text { combustion and description } \\
\text { of } \mathrm{CO} \text { conversion under both } \\
\text { kinetic- and } \\
\text { diffusion-controlled regimes }\end{array}$ & $\begin{array}{l}\text { Computational Fluid } \\
\text { Dynamics (CFD) } \\
\text { modelling, based on the } \\
\text { open-source finite volume } \\
\text { code OpenFOAM }{ }^{\circledR}\end{array}$ & [85] \\
\hline $\begin{array}{l}\text { Virtually reconstructed } \\
\text { foams }\end{array}$ & $\begin{array}{l}\text { Evaluation of the foam } \\
\text { geometry influence on the } \\
\text { transport phenomena }\end{array}$ & $\begin{array}{l}\text { Computational Fluid } \\
\text { Dynamics (CFD) } \\
\text { modelling }\end{array}$ & {$[86,87]$} \\
\hline $\begin{array}{l}\text { Foams with a wide range } \\
\text { of porosities }\end{array}$ & $\begin{array}{l}\text { Estimation of the specific } \\
\text { surface area of open-cell } \\
\text { foams as a function of either } \\
\text { cell diameter and porosity or } \\
\text { pore diameter and porosity. }\end{array}$ & $\begin{array}{c}\text { An analytical } \\
\text { Geometical model }\end{array}$ & [88] \\
\hline $\begin{array}{l}\text { Four types of open-cell } \\
\text { foams, characterized by } \\
\text { almost the same void fraction } \\
\text { but different PPI values }\end{array}$ & $\begin{array}{l}\text { Evaluation of the material } \\
\text { tortuosity influence on the } \\
\text { heat transfer. }\end{array}$ & $\begin{array}{c}\text { Discretized } \\
\text { mathematical model }\end{array}$ & [89] \\
\hline $\begin{array}{l}\text { An aluminum metal foam } \\
\text { and an aluminum } \\
\text { metal monolith }\end{array}$ & $\begin{array}{l}\text { Study of isothermal } \\
\text { adiabatic WGS process. }\end{array}$ & $\begin{array}{l}\text { An analytical model based } \\
\text { on power law rate } \\
\text { equation for the reaction } \\
\text { kinetics description. }\end{array}$ & [90] \\
\hline $\begin{array}{l}\text { Noble metals foam } \\
\text { structured catalysts }\end{array}$ & $\begin{array}{l}\text { Evaluation of the influence } \\
\text { of flow geometry on the } \\
\text { WGS performances. }\end{array}$ & Experimental tests & [91] \\
\hline Aluminum foams & $\begin{array}{l}\text { Description of the pressure } \\
\text { drops profile along } \\
\text { the catalyst. }\end{array}$ & $\begin{array}{l}\text { Computational fluid } \\
\text { dynamics simulations }\end{array}$ & [92] \\
\hline $\begin{array}{l}\text { Virtually generated models } \\
\text { with different porosities, } \\
\text { different cell sizes and } \\
\text { circular struts }\end{array}$ & $\begin{array}{l}\text { Estimation of the effect of the } \\
\text { geometrical properties (e.g., } \\
\text { cell size, porosity and strut } \\
\text { shape) on the } \\
\text { pressure drops. }\end{array}$ & $\begin{array}{l}\text { A virtually generated foam } \\
\text { model and 3D } \\
\text { printed replicas. }\end{array}$ & [93] \\
\hline
\end{tabular}


As it can be seen from Figure 7, while the differences between the outlet temperatures of $100 \%$ alumina and aluminum foams of both gas and solid phase are almost the same, a significant reduction in the difference between $100 \%$ alumina and aluminium foams is obtained in the gas phase compared to the solid phase. Indeed, a higher porosity value, meaning of a higher exchange area, resulted in an enhancement of tortuosity and gas-solid heat exchange area. A CFD modelling study of WGS single stage process in adiabatic condition has been done with the use of COMSOL Multiphysics $5.0^{\circledR}$, two types of reactor configurations have been tested: A packed bed reactor with powder catalyst and a structured foam catalytic reactor. The investigation results revealed that the use of highly conductive carrier allows to have a more uniform temperature profile along the catalytic bed, as a result of a reaction heat back diffusion from the output to the input of the bed. The heat redistribution origins an input temperature increase that improves the kinetic and, an outlet temperature decrease that promotes the thermodynamics of the system, resulting in a promising WGS process intensification [81]. The advantages achievable with the use of a structured catalyst compared to the powder one, in the WGS reaction, have been also remarked in an evaluation of a $\mathrm{Pt} / \mathrm{Re}$ based catalyst supported on $\mathrm{CeZrO}_{4}$ [52]. In this study a highly heat conductive foam washcoated with a primer of alumina was firstly impregnated with a ceria and zirconia salts precursors solution and then with the salt precursors of platinum and rhenium. The obtained results, validated with CFD simulations, evidenced an increase in the $\mathrm{CO}$ conversion in the case of the structured catalyst, due to the back diffusion of the reaction heat along the catalyst. Van Dijk et al. [90] achieved an isothermal adiabatic WGS process by dissipating the reaction heat through the catalyst support structure; two types of reactor configurations were tested, an aluminum metal foam and an aluminum metal monolith. The developed model, based on power law rate equation for the reaction kinetics description, was in good agreement with the experiments done with the monolithic reactor while, for the catalytic foam, some problems were found because of its large 3D structure. Moreover, a comparative study between monoliths and foams as carriers for the WGS reaction has been made by Palma et al. [51] by experimental tests and CFD simulation through COMSOL Multiphysics ${ }^{\circledR}$. Two $\mathrm{Pt} / \mathrm{CeO}_{2} / \mathrm{Al}_{2} \mathrm{O}_{3}$ based structured catalysts with a flow-through aluminum monolith and an open-cell aluminum foam used as carriers have been tested in stressful conditions (WHSV $=10.32 \mathrm{gCO} / \mathrm{g}_{\mathrm{CAT} / \mathrm{h}-1}$, tc $=107 \mathrm{~ms}$ and without any dilution), with the aim of minimizing the thermal dispersions. Both the monolith-based catalysts (PtCeWM) and the foam-based catalyst (PtCeWF10) showed, along the catalyst bed, a firstly zone characterized by a rapid temperature increase and a second one with an approximate isothermal profile. Also, the simulations confirmed the obtained experimental temperature profiles, with the presence of a first zone in which the low kinetics leads to a small increase of $\mathrm{CO}$ conversion and a rapid increase of the temperature, and a second zone, characterized by a high kinetics, where the $\mathrm{CO}$ conversion drives to the maximum value at an almost constant temperature value.

A deeper investigation of the heat transfer in both catalysts has also been made by the authors; the results are shown in Figure 8, in which $A$ and $C$ parts are related to the foam and B and D to the monolith; in particular, in A and B parts is depicted the surface plots of the axial and radial total heat flux $\left(\mathrm{W} / \mathrm{m}^{2}\right)$, while in $\mathrm{C}$ and $\mathrm{D}$ parts the temperature distributions are shown. Moreover, in Figure 8A,B the top scale reports the radial total heat flux values and the bottom scale the axial total heat flux values. As regard the foam, a negative axial flux was observed in the first zone and a positive axial flux in the second zone, while the radial flux was positive in the first zone of the foam and it became lower along the foam length. The foam temperature profile has been found to be homogeneous in both axial and radial directions, possibly originating by the tortuous flow field that allows both axial and radial dispersions. In the monolith, besides, a negative total axial flow was obtained in the first zone and a positive one in the last part, and a radial heat flux almost equal to zero was detected along the monolith. As concern the monolith temperature profile, a higher temperature in the gas phase was obtained at the beginning of the catalytic zone compared with the solid phase, due to a high heat transfer resistance at the solid-gas interface caused by the flow field developed in its channel. In order to evaluate the influence of flow geometry on the WGS performance, different reactor assemblages 
(axial and radial configurations) with noble metals foam structured catalysts have been made by Palma et al. [91]. The investigation showed a significant difference between the two configurations; in particular, higher performances were achieved in the case of radial reactor. Moreover, radial flow through the catalytic bed has also been tested as centripetal or centrifugal configuration, leading to the conclusion that the choice between them depends on the catalyst intrinsic activity and the reactor operating conditions.

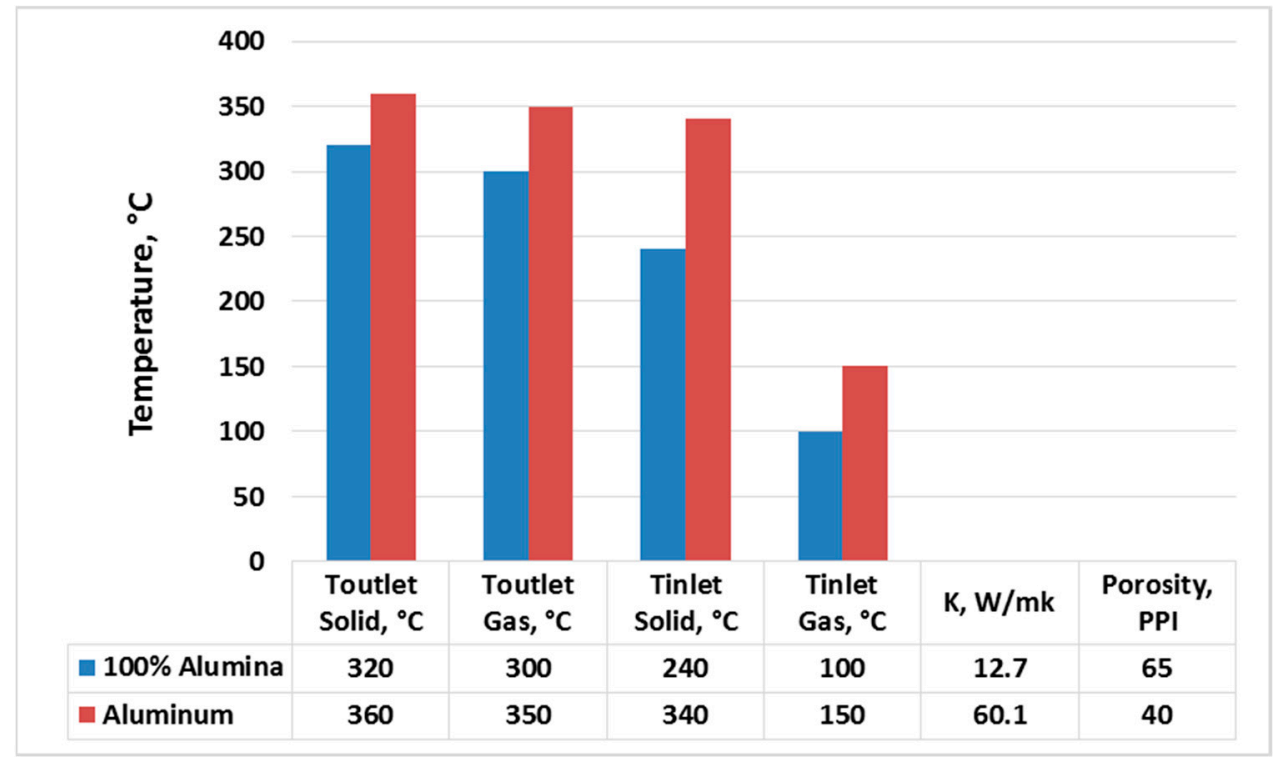

Figure 7. Temperatures profiles of $100 \%$ alumina and aluminum foams [88].

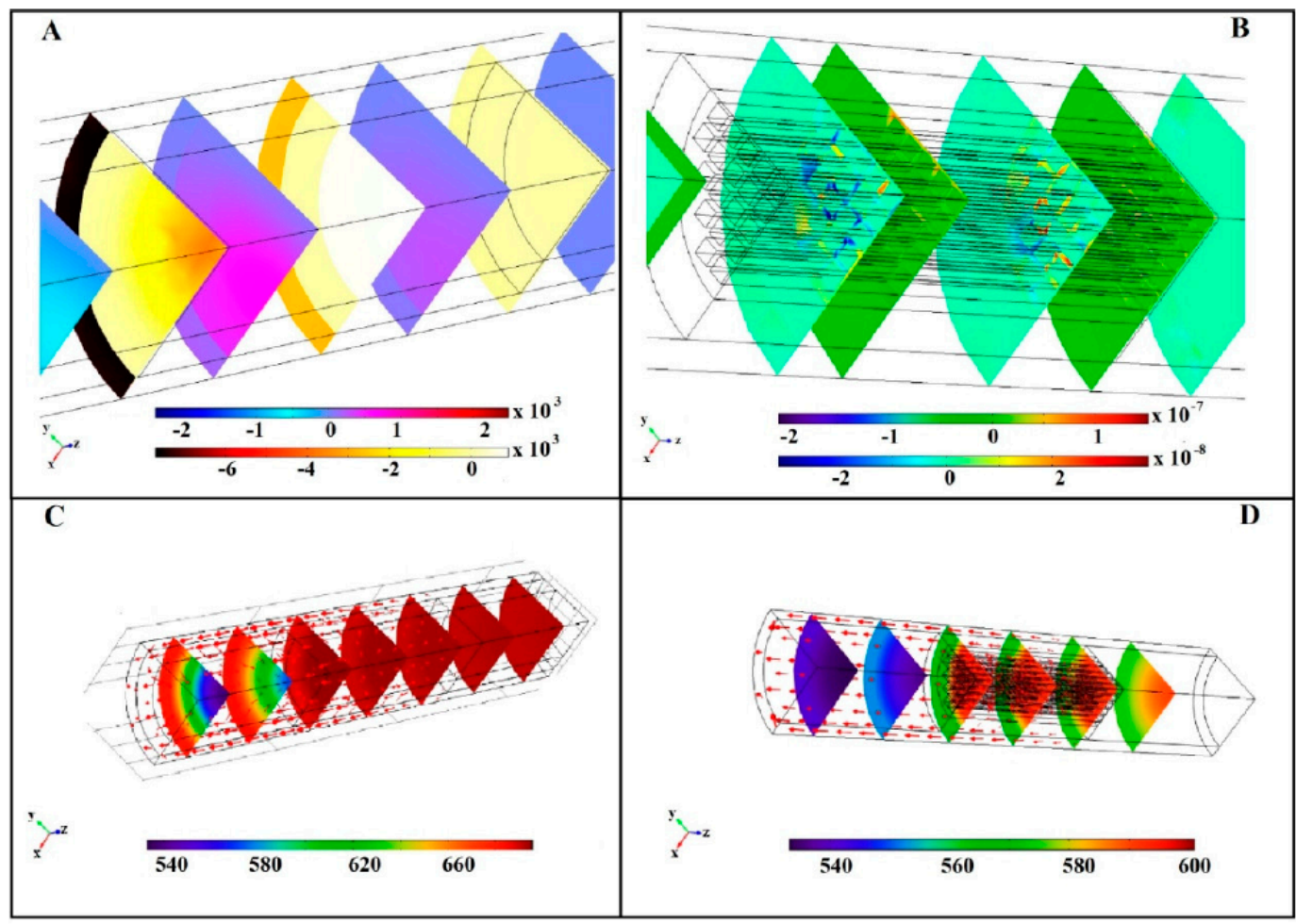

Figure 8. Temperature (K) in the 3D simulation domain: PtCeWF10 (A,C) and PtCeWM (B,D) [91].

Furthermore, another important characteristic for choosing an optimal catalyst's carrier is represented by the resistance offered to the gas flow, several studies have been devoted to the 
investigation of pressure drops across structured catalysts. Otaru et al. [92] compared experimental measurements of the pressure drops across porous aluminum foams with computational fluid dynamics simulations, finding a reliably prediction of the pressure drops behaviour within the Forchheimer regime. Also, Bracconi et al. [93], due to the presence of large discrepancies in the literature between experimental results and predictions by models, developed a virtually-generated foam model and 3D printed replicas, in order to diminish the structural differences between the CFD models and the real foams. The results of the study pointed out the effect of the geometrical properties (e.g., cell size, porosity and strut shape) on the pressure drop; in particular, they found that an increase of the cell diameter or of the void fraction lower the pressure drop across the support, and moreover, the average strut size is the key factor affecting the pressure losses. A specific engineering Ergun-like correlation was also developed by the authors, which has shown a satisfactory agreement with the experimental data.

\section{Conclusions and Outlook}

This short review has reported the recent advances in structured catalysts preparation and the use in water-gas shift reaction. The first part of the article has provided an overview of the most diffused preparation methods for the structured supports, of the most used coating techniques and of the mechanical and thermal stress evaluation techniques. In the second part of the review article, the results of a series of works were reported, on the catalytic activity and on the kinetics of structured catalysts for the water gas shift reaction. Finally, a review about some works concerning the studies and modelling of the transport in structured catalysts have been reported, with particular reference, but not exclusive, to the water gas shift reaction. The diffusion of new technologies for the design and preparation of complex structures, such as additive manufacturing techniques, coupled with the optimization of transport, mass and heat phenomena, constitute the premise for the design of innovative reactor configurations. In this regard, various catalytic formulations were proposed, deposited on both foam and monoliths. The choice of the carrier material appears crucial, being privileged the metallic supports having high thermal conductivity. Moreover, Pt-based catalyst displayed the highest conversion and the lowest activation energy. As a result, the structured catalyst seems to be the most promising way to realize a strong intensification of the water gas shift process, and the only feasible way to use this process in distributed production of hydrogen. In this regard, the future research will be focused on the development of less expensive formulations, having structures even more optimized under the point of view of heat and mass transfer.

Author Contributions: Conceptualization, M.M., M.C. and C.R.; methodology, M.M.; investigation, M.M., C.R. and M.C.; resources, V.P.; data curation, M.M., C.R. and M.C.; writing-original draft preparation, M.M., C.R. and M.C.; writing-review and editing, M.M., C.R. and M.C.; visualization, M.M.; supervision, V.P.; project administration, V.P.; funding acquisition, V.P.

Funding: This work has received funding from the European Union's Horizon 2020 research and innovation programme, under the Marie Skłodowska-Curie grant agreement (No. 734561).

Conflicts of Interest: The authors declare no conflict of interest.

\section{References and Notes}

1. Bukur, D.B.; Todic, B.; Elbashir, N. Role of water-gas-shift reaction in Fischer-Tropsch synthesis on iron catalysts: A review. Catal. Today 2016, 275, 66-75. [CrossRef]

2. Hallac, B.B.; Brown, J.C.; Stavitski, E.; Harrison, R.G.; Argyle, M.D. In Situ UV-Visible Assessment of Iron-Based High-Temperature Water-Gas Shift Catalysts Promoted with Lanthana: An Extent of Reduction Study. Catalysts 2018, 8, 63. [CrossRef]

3. Montenegro Camacho, Y.S.; Bensaid, S.; Lorentzou, S.; Russo, N.; Fino, D. Structured catalytic reactor for soot abatement in a reducing atmosphere. Fuel Process. Technol. 2017, 167, 462-473. [CrossRef] 
4. Lucci, F.; Della Torre, A.; Montenegro, G.; Kaufmann, R.; Dimopoulos Eggenschwiler, P. Comparison of geometrical, momentum and mass transfer characteristics of real foams to Kelvin cell lattices for catalyst applications. Int. J. Hydrogen Energy 2017, 108, 341-350. [CrossRef]

5. González-Castaño, M.; Le Saché, E.; Ivanova, S.; Romero-Sarria, F.; Centeno, M.A.; Odriozola, J.A. Tailoring structured WGS catalysts: Impact of multilayered concept on the water surface interactions. Appl. Catal. B Environ. 2018, 222, 124-132. [CrossRef]

6. Wu, D.; Kong, S.; Zhang, H.; Li, Y. Mechanical stability of monolithic catalysts: Factors affecting washcoat adhesion and cohesion during preparation. AIChE J. 2014, 60, 2765-2773. [CrossRef]

7. Palma, V.; Pisano, D.; Martino, M.; Ciambelli, P. Structured catalysts with high thermoconductive properties for the intensification of Water Gas Shift process. Chem. Eng. J. 2016, 304, 544-551. [CrossRef]

8. Tronconi, E.; Groppi, G.; Visconti, C.G. Structured catalysts for non-adiabatic applications. Curr. Opin. Chem. Eng. 2014, 5, 55-67. [CrossRef]

9. Lim, J.W.; Choi, Y.; Yoon, H.S.; Park, Y.K.; Yim, J.H.; Jeon, J.K. Extrusion of honeycomb monoliths employed with activated carbon-LDPE hybrid materials. J. Ind. Eng. Chem. 2010, 16, 51-56. [CrossRef]

10. Govender, S.; Friedrich, H.B. Monoliths: A Review of the Basics, Preparation Methods and Their Relevance to Oxidation. Catalysts 2017, 7, 62. [CrossRef]

11. González-Castaño, M.; Reina, T.R.; Ivanova, S.; Martínez Tejada, L.M.; Centeno, M.A.; Odriozola, J.A. $\mathrm{O}_{2}$-assisted Water Gas Shift reaction over structured Au and Pt catalysts. Appl. Catal. B Environ. 2016, 185, 337-343. [CrossRef]

12. Avila, P.; Montes, M.; Miró, E.E. Monolithic reactors for environmental applications: A review on preparation technologies. Chem. Eng. J. 2005, 109, 11-36. [CrossRef]

13. García-Moncada, N.; Groppi, G.; Beretta, A.; Romero-Sarria, F.; Odriozola, J.A. Metal Micro-Monoliths for the Kinetic Study and the Intensification of the Water Gas Shift Reaction. Catalysts 2018, 8, 594. [CrossRef]

14. Albaldawi, R.A.H.; Shyaa, A.K.; Hammendy, B.M.H. Experimental Study on the Effect of Insertion of Copper Lessing Rings in Phase Change Material (PCM) on the Performance of Thermal Energy Storage Unit. Al Khwarizmi Eng. J. 2015, 11, 60-72.

15. Ptáček, P.; Lang, K.; Šoukal, F.; Opravil, T.; Tvrdík, L.; Novotný, R. Preparation and properties of nanostructured ceramic foam from kaolinite. Powder Technol. 2014, 253, 29-34. [CrossRef]

16. Al Amin Muhamad Nor, M.; Chain Hong, L.; Arifin Ahmad, Z.; Md Akil, H. Preparation and characterization of ceramic foam produced via polymeric foam replication method. J. Mater. Process. Technol. 2008, 207, 235-239. [CrossRef]

17. Zhang, H.; Han, Y.; Chen, F.; Wen, J. Fabrication of Porous Ceramic Scaffolds via Polymeric Sponge Method Using Sol-Gel Derived Strontium Doped Hydroxyapatite. Appl. Mech. Mater. 2011, 117-119, 829-832. [CrossRef]

18. Qiao, J.; Wen, Y. Preparation and characterization of magnesium aluminate $\left(\mathrm{MgAl}_{2} \mathrm{O}_{4}\right)$ spinel ceramic foams via direct foam-gelcasting. Ceram. Int. 2019, 46, 678-684. [CrossRef]

19. Pokhrel, A.; Nam Seo, D.; Taek Lee, S.; Jin Kim, I. Processing of Porous Ceramics by Direct Foaming: A Review. J. Korean Ceram. Soc. 2013, 50, 93-102. [CrossRef]

20. García-Moreno, F. Commercial Applications of Metal Foams: Their Properties and Production. Materials 2016, 9, 85. [CrossRef]

21. Dukhan, N. Metal Foams: Fundamentals and Applications; DEStech Publications, Inc.: Lancaster, PA, USA, 2013.

22. Parra-Cabrera, C.; Achille, C.; Kuhn, S.; Ameloot, R. 3D printing in chemical engineering and catalytic technology: Structured catalysts, mixers and reactors. Chem. Soc. Rev. 2018, 47, 209-230. [CrossRef]

23. Palma, V.; Ricca, A.; Meloni, E.; Martino, M.; Miccio, M.; Ciambelli, P. Experimental and numerical investigations on structured catalysts for methane steam reforming intensification. J. Clean. Prod. 2016, 111, 217-230. [CrossRef]

24. Thimmaraju, N.; Pratap, S.R.; Senthilkumar, M.; Mohamed Shamshuddin, S.Z. Honeycomb Monolith Coated with $\mathrm{Mo}(\mathrm{VI}) / \mathrm{ZrO}_{2}$ as a Versatile Catalyst System for Liquid Phase Transesterification. J. Korean Chem. Soc. 2012, 56, 563-570. [CrossRef]

25. Ahn, H.G.; Lee, J.D. Performance of double wash-coated monolith catalyst in selective catalytic reduction of NOx with propene. Stud. Surf. Sci. Catal. 2003, 146, 701-704. [CrossRef]

26. Bahuguna, G.; Kumar Mishra, N.; Chaudhary, P.; Kumar, A.; Singh, R. Thin Film Coating through Sol-Gel Technique. Res. J. Chem. Sci. 2016, 6, 65-72. 
27. Tao, Y.; Pescarmona, P.P. Nanostructured Oxides Synthesised via $\mathrm{scCO}_{2}$-Assisted Sol-Gel Methods and Their Application in Catalysis. Catalysts 2018, 8, 212. [CrossRef]

28. Giornelli, T.; Löfberg, A.; Bordes-Richard, E. Preparation and characterization of $\mathrm{VOx} / \mathrm{TiO}_{2}$ catalytic coatings on stainless steel plates for structured catalytic reactors. Appl. Catal. A Gen. 2006, 305, 197. [CrossRef]

29. Deganello, F.; Tyagi, A.K. Solution combustion synthesis, energy and environment: Best parameters for better materials. Prog. Cryst. Growth Charact. 2018, 64, 23-61. [CrossRef]

30. Ercolino, G.; Karimi, S.; Stelmachowski, P.; Specchia, S. Catalytic combustion of residual methane on alumina monoliths and open cell foams coated with $\mathrm{Pd} / \mathrm{Co}_{3} \mathrm{O}_{4}$. Chem. Eng. J. 2017, 326, 339-349. [CrossRef]

31. Basile, F.; Benito, P.; Fornasari, G.; Rosetti, V.; Scavetta, E.; Tonelli, D.; Vaccari, A. Electrochemical synthesis of novel structured catalysts for $\mathrm{H}_{2}$ production. Appl. Catal. B Environ. 2009, 91, 563-572. [CrossRef]

32. Ho, P.H.; Ambrosetti, M.; Groppi, G.; Tronconi, E.; Jaroszewicz, J.; Ospitali, F.; Rodriguez-Castellon, E.; Fornasari, G.; Vaccari, A.; Benito, P. One-step electrodeposition of $\mathrm{Pd}-\mathrm{CeO}_{2}$ on high pore density foams for environmental catalytic processes. Catal. Sci. Technol. 2018, 8, 4678-4689. [CrossRef]

33. Meille, V. Review on methods to deposit catalysts on structured surfaces. Appl. Catal. A Gen. 2006, 315, 1-17. [CrossRef]

34. Montebelli, A.; Visconti, C.G.; Groppi, G.; Tronconi, E.; Cristiani, C.; Ferreira, C.; Kohler, S. Methods for the catalytic activation of metallic structured substrates. Catal. Sci. Technol. 2014, 4, 2846-2870. [CrossRef]

35. Moritz, K.; Dietze, C.; Voigt, C.; Hubálková, J.; Aneziris, C.G. Porous alumina coatings on carbon-bonded foam filters by electrophoretic deposition. Ceram. Int. 2019, 45, 10701-10706. [CrossRef]

36. Linga Reddy, E.; Chan Lee, H.; Hyun Kim, D. Steam reforming of methanol over structured catalysts prepared by electroless deposition of $\mathrm{Cu}$ and $\mathrm{Zn}$ on anodically oxidized alumina. Int. J. Hydrogen Energy 2015, 40, 2509-2517. [CrossRef]

37. Fukuhara, C.; Ohkura, H.; Gonohe, K.; Igarashi, A. Low-temperature water-gas shift reaction of plate-type copper-based catalysts on an aluminum plate prepared by electroless plating. Appl. Catal. A Gen. 2005, 279, 195-203. [CrossRef]

38. El-Eskandarany, M.S. Introduction. In Mechanical Alloying, 2nd ed.; El-Eskandarany, M.S., Ed.; William Andrew Publishing: Oxford, UK, 2015; pp. 1-12.

39. Faust, M.; Dinkel, M.; Bruns, M.; Brase, S.; Seipenbusch, M. Support Effect on the Water Gas Shift Activity of Chemical Vapor Deposition-Tailored-Pt/TiO 2 Catalysts. Ind. Eng. Chem. Res. 2017, 56, 3194-3203. [CrossRef]

40. Nassoy, F.; Pinault, M.; Descarpentries, J.; Vignal, T.; Banet, P.; Coulon, P.E.; Goislard de Monsabert, T.; Hauf, H.; Aubert, P.H.; Reynaud, C.; et al. Single-Step Synthesis of Vertically Aligned Carbon Nanotube Forest on Aluminium Foils. Nanomaterials 2019, 9, 1590. [CrossRef]

41. Minett, D.R.; O’Byrne, J.P.; Jones, M.D.; Ting, V.P.; Mays, T.J.; Mattia, D. One-step production of monolith-supported long carbon nanotube arrays. CARBON 2013, 51, 327-334. [CrossRef]

42. Johnson, R.W.; Hultqvist, A.; Bent, S.F. A brief review of atomic layer deposition: From fundamentals to applications. Mater. Today 2014, 17, 236-246. [CrossRef]

43. Lee, H.Y.; An, G.J.; Piao, S.J.; Ahn, D.Y.; Kim, M.T.; Min, Y.S. Shrinking Core Model for Knudsen Diffusion-Limited Atomic Layer Deposition on a Nanoporous Monolith with an Ultrahigh Aspect Ratio. J. Phys. Chem. C 2010, 114, 18601-18606. [CrossRef]

44. Hassannejad, H.; Moghaddasi, M.; Saebnoori, E.; Baboukan, A.R. Microstructure, deposition mechanism and corrosion behavior ofnanostructured cerium oxide conversion coating modified withchitosan on AA2024 aluminum alloy. J. Alloys Compd. 2017, 725, 968-975. [CrossRef]

45. Milošev, I.; Frankel, G.S. Review-Conversion Coatings Based on Zirconium and/or Titanium. J. Electrochem. Soc. 2018, 165, C127-C144. [CrossRef]

46. Szunerits, S.; Thouin, L. Microelectrode Arrays. In Handbook of Electrochemistry; Zoski, C.G., Ed.; Elsevier: Amsterdam, The Netherlands, 2007; pp. 391-428.

47. Palma, V.; Martino, M.; Truda, L. Nano- $\mathrm{CeO}_{2}$ coating on Aluminum Foam Carriers for Structured Catalysts Preparation. Chem. Eng. Trans. 2019, 73, 127-132. [CrossRef]

48. SEM images were acquired at the laboratories of the industrial engineering department of the University of Salerno.

49. Wheeler, C.; Jhalani, A.; Klein, E.J.; Tummala, S.; Schmidt, L.D. The water-gas-shift reaction at short contact times. J. Catal. 2004, 223, 191-199. [CrossRef] 
50. Özyönüm, G.N.; Yildirim, R. Water gas shift activity of Au Re catalyst over microstructured cordierite monolith wash-coated by ceria. Int. J. Hydrogen Energy 2016, 41, 5513-5521. [CrossRef]

51. Palma, V.; Pisano, D.; Martino, M. Comparative Study between Aluminum Monolith and Foam as Carriers for the Intensification of the CO Water Gas Shift Process. Catalysts 2018, 8, 489. [CrossRef]

52. Palma, V.; Pisano, D.; Martino, M. Structured noble metal-based catalysts for the WGS process intensification. Int. J. Hydrogen Energy 2018, 43, 11745-11754. [CrossRef]

53. Visconti, C.G. Alumina: A key-component of structured catalysts for process intensification. Trans. Indian Ceram. Soc. 2012, 71, 123-136. [CrossRef]

54. Kuan Teo, J.S.; Pheng Teh, S.; Addiego, W.P.; Zhong, Z.; Borgna, A.; Truitt, R.E. Monolithic gold catalysts: Preparation and their catalytic performances in water gas shift and $\mathrm{CO}$ oxidation reactions. Int. J. Hydrogen Energy 2011, 36, 5763-5774. [CrossRef]

55. Rao Peela, N.; Mubayi, A.; Kunzru, D. Washcoating of $\gamma$-alumina on stainless steel microchannels. Catal. Today 2009, 147S, S17-S23. [CrossRef]

56. Cristiani, C.; Visconti, C.G.; Finocchio, E.; Gallo Stampino, P.; Forzatti, P. Towards the rationalization of the washcoating process conditions. Catal. Today 2009, 147S, S24-S29. [CrossRef]

57. Katheria, S.; Deo, G.; Kunzru, D. Washcoating of $\mathrm{Ni} / \mathrm{MgAl}_{2} \mathrm{O}_{4}$ Catalyst on FeCralloy Monoliths for Steam Reforming of Methane. Energy Fuels 2017, 31, 3143-3153. [CrossRef]

58. Wójcik, S.; Ercolino, G.; Gajewska, M.; Moncada Quintero, C.W.; Specchia, S.; Kotarba, A. Robust $\mathrm{Co}_{3} \mathrm{O}_{4}\left|\alpha-\mathrm{Al}_{2} \mathrm{O}_{3}\right|$ cordierite structured catalyst for $\mathrm{N}_{2} \mathrm{O}$ abatement-Validation of the SCS method for active phase synthesis and deposition. Chem. Eng. J. 2019, 377, 120088. [CrossRef]

59. Pennemann, H.; Dobra, M.; Wichert, M.; Kolb, G. Optimization of Wash-Coating Slurries as Catalyst Carrier for Screen Printing into Microstructured Reactors. Chem. Eng. Technol. 2013, 36, 1033-1041. [CrossRef]

60. Yasaki, S.; Yoshino, Y.; Ihara, K.; Ohkubo, K. Method of Manufacturing an Exhaust Gas Purifying Catalyst. U.S. Patent 5208206 (A), 4 May 1993.

61. Pérez, H.; Navarro, P.; Montes, M. Deposition of SBA-15 layers on Fecralloy monoliths by washcoating. Chem. Eng. J. 2010, 158, 325-332. [CrossRef]

62. Zapf, R.; Kolb, G.; Pennemann, H.; Hessel, V. Basic Study of Adhesion of Several Alumina-based Washcoats Deposited on Stainless Steel Microchannels. Chem. Eng. Technol. 2006, 29, 1509-1512. [CrossRef]

63. Stefanescu, A.; van Veen, A.C.; Mirodatos, C.; Beziat, J.C.; Duval-Brunel, E. Wall coating optimization for microchannel reactors. Catal. Today 2007, 125, 16-23. [CrossRef]

64. Agrafiotis, C.; Tsetsekou, A. The effect of powder characteristics on washcoat quality. Part I: Alumina washcoats. J. Eur. Ceram. Soc. 2000, 20, 815. [CrossRef]

65. Ugues, D.; Specchia, S.; Saracco, G. Optimal Microstructural Design of a Catalytic Premixed FeCrAlloy Fiber Burner for Methane Combustion. Ind. Eng. Chem. Res. 2004, 43, 1990-1998. [CrossRef]

66. Yang, J.; Blanco-García, P.; Holt, E.M.; Wagland, A.; Huang, K.; Salman, A.D. Adhesive strength measurement of catalyst support. Powder Technol. 2018, 340, 465-472. [CrossRef]

67. Yang, J.; Holt, E.M.; Blanco-García, P.; Wagland, A.; Hounslow, M.J.; Salman, A.D. A novel technique for quantifying the cohesivestrength of washcoat. Chem. Eng. Res. Des. 2016, 110, 108-113. [CrossRef]

68. Bobadilla, L.F.; Muñoz-Murillo, A.; Laguna, O.H.; Centeno, M.A.; Odriozola, J.A. Does shaping catalysts modify active phase sites? A comprehensive in situ FTIR spectroscopic study on the performance of a model $\mathrm{Ru} / \mathrm{Al}_{2} \mathrm{O}_{3}$ catalyst for the $\mathrm{CO}$ methanation. Chem. Eng. J. 2019, 357, 248-257. [CrossRef]

69. Goguet, A.; Meunier, F.C.; Tibiletti, D.; Breen, J.P.; Burch, R. Spectrokinetic Investigation of Reverse Water-Gas-Shift Reaction Intermediates over a Pt/CeO 2 Catalyst. J. Phys. Chem. B 2004, 108, 20240-20246. [CrossRef]

70. Quiney, A.S.; Germani, G.; Schuurman, Y. Optimization of a water-gas shift reactor over a Pt/ceria/alumina monolith. J. Power Sources 2006, 160, 1163-1169. [CrossRef]

71. Ruettinger, W.; Ilinich, O.; Farrauto, R.J. A new generation of water gas shift catalysts for fuel cell applications. J. Power Sources 2003, 118, 61-65. [CrossRef]

72. Palma, V.; Martino, M. Aluminum Foam based Catalysts for the CO-WGS Reaction. Chem. Eng. Trans. 2018, 70, 1225-1230. [CrossRef]

73. Rebrov, E.V. Advances in water-gas shift technology: Modern catalysts and improved reactor concepts. In Advances in Clean Hydrocarbon Fuel Processing; Khan, M.R., Ed.; Woodhead Publishing: Cambridge, UK, 2011; pp. 387-412. 
74. Tonkovich, A.Y.; Zilka, J.L.; LaMont, M.J.; Wang, Y.; Wegeng, R.S. Microchannel reactors for fuel processing applications. I. Water gas shift reactor. Chem. Eng. Sci. 1999, 54, 2947-2951. [CrossRef]

75. Goerke, O.; Pfeifer, P.; Schubert, K. Water gas shift reaction and selective oxidation of CO in microreactors. Appl. Catal. A Gen. 2004, 263, 11-18. [CrossRef]

76. Germani, G.; Schuurman, Y. Water-gas shift kinetics over $\mu$-structured $\mathrm{Pt} / \mathrm{CeO} 2 / \mathrm{Al}_{2} \mathrm{O}_{3}$ cataysts. AIChE J. 2006, 52, 1806-1813. [CrossRef]

77. Quiney, A.S.; Schuurman, Y. Kinetic modelling of CO conversion over a Cu/ceria catalyst. Chem. Eng. Sci. 2007, 62, 5026-5032. [CrossRef]

78. Byron Smith, R.J.; Muruganandam, L.; Murthy, S.S. A Review of the Water Gas Shift Reaction Kinetics. Int. J. Chem. React. Eng. 2010, 8, 1542-6580. [CrossRef]

79. Maestri, M.; Livio, D.; Beretta, A.; Groppi, G. Hierarchical Refinement of Microkinetic Models: Assessment of the Role of the WGS and r-WGS Pathways in $\mathrm{CH}_{4}$ Partial Oxidation on Rh. Ind. Eng. Chem. Res. 2014, 53, 10914-10928. [CrossRef]

80. García-Moncada, N.; Bobadilla, L.F.; Poyato, R.; López-Cartes, C.; Romero-Sarria, F.; Centeno, M.Á.; Odriozola, J.A. A direct in situ observation of water-enhanced proton conductivity of Eu-doped $\mathrm{ZrO}_{2}$ : Effect on WGS reaction. Appl. Catal. B Environ. 2018, 231, 343-356. [CrossRef]

81. Palma, V.; Pisano, D.; Martino, M. CFD modeling of the influence of carrier thermal conductivity for structured catalysts in the WGS reaction. Chem. Eng. Sci. 2018, 178, 1-11. [CrossRef]

82. Monno, M.; Negri, D.; Mussi, V.; Aghaei, P.; Groppi, G.; Tronconi, E.; Strano, M. Cost-Efficient Aluminum Open-Cell Foams: Manufacture, Characterization, and Heat Transfer Measurements. Adv. Eng. Mater. 2018, 20, 1701032. [CrossRef]

83. Bianchi, E.; Heidig, T.; Visconti, C.G.; Groppi, G.; Freund, H.; Tronconi, E. Heat Transfer Properties of Metal Foam Supports for Structured Catalysts: Wall Heat Transfer Coefficient. Catal. Today 2013, 216, 121-134. [CrossRef]

84. Bianchi, E.; Groppi, G.; Schwieger, W.; Tronconi, E.; Freund, H. Numerical Simulation of Heat Transfer in the Near-Wall Region of Tubular Reactors Packed with Metal Open-Cell Foams. Chem. Eng. J. 2015, 264, 268-279. [CrossRef]

85. Della Torre, A.; Lucci, F.; Montenegro, G.; Onorati, A.; Dimopoulos Eggenschwiler, P.; Tronconi, E.; Groppi, G. CFD Modeling of Catalytic Reactions in Open-Cell Foam Substrates. Comput. Chem. Eng. 2016, 92, 55-63. [CrossRef]

86. Bracconi, M.; Ambrosetti, M.; Maestri, M.; Groppi, G.; Tronconi, E. A Fundamental Analysis of the Influence of the Geometrical Properties on the Effective Thermal Conductivity of Open-Cell Foams. Chem. Eng. Process. Process Intensif. 2018, 129, 181-189. [CrossRef]

87. Bracconi, M.; Ambrosetti, M.; Maestri, M.; Groppi, G.; Tronconi, E. A Fundamental Investigation of Gas/Solid Mass Transfer in Open-Cell Foams Using a Combined Experimental and CFD Approach. Chem. Eng. J. 2018, 352, 558-571. [CrossRef]

88. Ambrosetti, M.; Bracconi, M.; Groppi, G.; Tronconi, E. Analytical Geometrical Model of Open Cell Foams with Detailed Description of Strut-Node Intersection. Chem. Ing. Tech. 2017, 89, 915-925. [CrossRef]

89. Palma, V.; Pisano, D.; Martino, M.; Ricca, A.; Ciambelli, P. High Thermal Conductivity Structured Carriers for Catalytic Processes Intensification. Chem. Eng. Trans. 2015, 43, 2047-2052. [CrossRef]

90. Van Dijk, H.A.J.; Boon, J.; Nyqvist, R.N.; van den Brink, R.W. Development of a Single Stage Heat Integrated Water-Gas Shift Reactor for Fuel Processing. Chem. Eng. J. 2010, 159, 182-189. [CrossRef]

91. Palma, V.; Palo, E.; Ciambelli, P. Structured Catalytic Substrates with Radial Configurations for the Intensification of the WGS Stage in $\mathrm{H}_{2}$ Production. Catal. Today 2009, 147, S107-S112. [CrossRef]

92. Otaru, A.J.; Morvan, H.P.; Kennedy, A.R. Measurement and Simulation of Pressure Drop across Replicated Porous Aluminium in the Darcy-Forchheimer Regime. Acta Mater. 2018, 149, 265-273. [CrossRef]

93. Bracconi, M.; Ambrosetti, M.; Okafor, O.; Sans, V.; Zhang, X.; Ou, X.; Da Fonte, C.P.; Fan, X.; Maestri, M.; Groppi, G.; et al. Investigation of pressure drop in 3D replicated open-cell foams: Coupling CFD with experimental data on additively manufactured foams. Chem. Eng. J. 2018, 377, 120123. [CrossRef]

(C) 2019 by the authors. Licensee MDPI, Basel, Switzerland. This article is an open access article distributed under the terms and conditions of the Creative Commons Attribution (CC BY) license (http://creativecommons.org/licenses/by/4.0/). 